\title{
The immunomodulatory effect of plant lectins: a review with emphasis on ArtinM properties
}

\author{
Maria A. Souza • Fernanda C. Carvalho • \\ Luciana P. Ruas • Rafael Ricci-Azevedo • \\ Maria Cristina Roque-Barreira
}

Received: 30 October 2012 /Revised: 6 December 2012 / Accepted: 9 December 2012 / Published online: 9 January 2013

(C) The Author(s) 2013. This article is published with open access at Springerlink.com

\begin{abstract}
Advances in the glycobiology and immunology fields have provided many insights into the role of carbohydrate-protein interactions in the immune system. We aim to present a comprehensive review of the effects that some plant lectins exert as immunomodulatory agents, showing that they are able to positively modify the immune response to certain pathological conditions, such as cancer and infections. The present review comprises four main themes: (1) an overview of plant lectins that exert immunomodulatory effects and the mechanisms accounting for these activities; (2) general characteristics of the immunomodulatory lectin ArtinM from the seeds of Artocarpus heterophyllus; (3) activation of innate immunity cells by ArtinM and consequent induction of Th1 immunity; (4) resistance conferred by ArtinM administration in infections with intracellular pathogens, such as Leishmania (Leishmania) major, Leishmania (Leishmania) amazonensis, and Paracoccidioides brasiliensis. We believe that this review will be a valuable resource for more studies in this relatively neglected area of research, which has the potential to reveal carbohydrate targets for novel prophylactic and therapeutic strategies.
\end{abstract}

Keywords Plantlectins · ArtinMlectin - Immunomodulation · Toll-like receptor $\cdot$ Leishmania $\cdot$ Paracoccidioides brasiliensis

\footnotetext{
M. A. Souza

Instituto de Ciências Biomédicas, Universidade Federal de

Uberlândia, Uberlândia, MG, Brazil

F. C. Carvalho $\cdot$ L. P. Ruas • R. Ricci-Azevedo

M. C. Roque-Barreira $(\square)$

Departamento de Biologia Celular e Molecular e Bioagentes

Patogênicos, Faculdade de Medicina de Ribeirão Preto,

Universidade de São Paulo, 14049900 Ribeirão Preto,

São Paulo, Brazil

e-mail: mcrbarre@fmrp.usp.br
}

\begin{tabular}{|c|c|}
\hline Abbreviations & \\
\hline ArtinM & $\begin{array}{l}\text { Artocarpus heterophyllus lectin manose } \\
\text { binding }\end{array}$ \\
\hline ML & Mistletoe lectin \\
\hline rML & Recombinant mistletoe lectin \\
\hline RIPs & Type-2 ribosomes inactivating proteins \\
\hline RNA & Ribonucleic acid \\
\hline NK & Natural killer cells \\
\hline IL-12 & Interleukin - (12) \\
\hline IFN- $\gamma$ & Interferon gamma \\
\hline TLR & Toll-like receptor \\
\hline TNF- $\alpha$ & Tumor necrosis factor-alpha \\
\hline Th1 & $\mathrm{T}$ helper 1 \\
\hline Th2 & $\mathrm{T}$ helper 2 \\
\hline Th17 & T helper 17 \\
\hline MHC II & Major histocompatibility complex class II \\
\hline KML & Korean mistletoe lectin \\
\hline $\begin{array}{l}\text { PHA-E and } \\
\text { PHA-L }\end{array}$ & Phytohaemagglutinin \\
\hline Con A & Concanavalin A \\
\hline PSA & Pisum sativum agglutinin \\
\hline WGA & Wheat germ agglutinin \\
\hline Cramoll & Cratylia mollis lectin \\
\hline BanLec & Lectin from Musa paradisiacal \\
\hline Conbr & Lectin from Canavalia brasiliensis \\
\hline DrosL & Dioclea rostrata lectin \\
\hline DvioL & Dioclea violacea lectin \\
\hline Dvirl & Dioclea virgata lectin \\
\hline Garlic & Lectin from Alium sativum \\
\hline PAA & $\begin{array}{l}\text { Pisum arvense agglutinin (lectin from } \\
\text { Pisum arvense) }\end{array}$ \\
\hline PWM & $\begin{array}{l}\text { Pokeweed mitogen (lectin from Phytolacca } \\
\text { Americana) }\end{array}$ \\
\hline SBA & Soybean agglutinin \\
\hline PNA & Peanut agglutinin \\
\hline AAL & Aleuria aurantia lectin \\
\hline
\end{tabular}




$\begin{array}{ll}\text { ScLL } & \text { Synadenium carinatum lectin latex } \\ \text { UEA-1 } & \text { Ulex europaeus agglutinin } \\ \text { CTL } & \text { Cytotoxic T lymphocytes } \\ \text { NOD } & \text { Non-obese diabetic mice } \\ \text { JRL } & \text { Jacalin-related lectins } \\ \text { CRD } & \text { Carbohydrate-recognition domain } \\ \text { HRP } & \text { Horseradish peroxidase } \\ \text { rArtinM } & \text { Recombinant ArtinM } \\ \text { NO } & \text { Nitric oxide } \\ \text { PAMPs } & \text { Pathogen-associated molecular patterns } \\ \text { TIR } & \text { Toll/interleukin-1 receptor } \\ \text { MyD88 } & \text { Myeloid differentiation primary response } \\ & \text { gene } 88 \\ \text { PCM } & \text { Paracoccidioidomycosis } \\ \text { CFU } & \text { Colony-forming units }\end{array}$

\section{Overview of immunomodulatory plant lectins}

Lectins are carbohydrate-binding proteins of non-immune origin. They are involved in various biological processes, including cell-cell recognition, cell proliferation, cell migration, cell adhesion to the extracellular matrix, and hostparasite interactions [1, 2]. Since the 1960s, plant lectins have been extensively used as valuable tools in biomedical research, because of their interactions with receptor-linked glycans on cell surfaces may trigger cell signaling and biochemical responses.

Several plant lectins exert immunomodulatory activities that are initiated by their interaction with glycan's moieties present over the surface of immune cells. Such interaction may trigger signal transduction, to produce certain cytokines (Table 1) and induce efficient immune responses against tumors or microbial infections. Hence, immunomodulatory lectins have potential pharmaceutical applications or may help to identify sugar targets for new therapeutic strategies.

The European mistletoe (Viscum album) contains the most noticeable plant lectin endowed with immunomodulatory and antitumor activities. Mistletoe lectins (ML) type I, II and III are a group of glycosylated, 56-64 kDa cytotoxic proteins, which consist of two non-covalently associated pairs of disulfide-linked A-B dimers and are considered to

Table 1 Some plant lectins that induce cytokines production

\begin{tabular}{|c|c|c|c|}
\hline Lectin & Source & Cytokine & Reference \\
\hline \multirow[t]{3}{*}{ ArtinM } & \multirow[t]{3}{*}{ Artocarpus heterophyllus } & IL-12 and IL-10 (murine macrophages and dendritic cells) & {$[26,74,75]$} \\
\hline & & TNF- $\alpha$ (murine mast cells) & {$[117]$} \\
\hline & & IL-10/IFN- $\gamma$ (murine spleen cells) & [118] \\
\hline Banlec & Musa paradisiaca & IFN- $\gamma$, IL-10, and IL-4 (murine spleen cells) & [29] \\
\hline \multirow[t]{3}{*}{ ConA } & \multirow[t]{3}{*}{ Canavalia ensiformis } & IFN- $\gamma$ (murine spleen cells) & {$[75]$} \\
\hline & & IFN- $\gamma$ and IL-2 (murine spleen cells) & {$[25]$} \\
\hline & & IL-5, IL-10, TNF- $\alpha$, and IFN- $\gamma$ (human peripheral blood mononuclear cells-PBMCs) & [119] \\
\hline \multirow[t]{2}{*}{ Conbr } & \multirow[t]{2}{*}{ Canavalia brasiliensis } & IL-5, IL-10, TNF- $\alpha$, and IFN- $\gamma$ (human PBMCs) & [119] \\
\hline & & IFN- $\gamma$ (murine spleen cells) & {$[75]$} \\
\hline Cramoll & Cratylia mollis & IFN- $\gamma$ (murine spleen cells) & {$[28]$} \\
\hline \multirow[t]{2}{*}{ DrosL } & \multirow[t]{2}{*}{ Dioclea rostrata } & IL-5, IL-10, TNF- $\alpha$, and IFN- $\gamma$ (human PBMCs) & [119] \\
\hline & & TNF- $\alpha$ and IL $1-\beta$ (peritoneal cavity of rat) & {$[120]$} \\
\hline Dviol & Dioclea violacea & IL-5 (human PBMCs) & [119] \\
\hline Dvirl & Dioclea virgata & IL-5, IL-10, TNF- $\alpha$, and IFN- $\gamma$ (human PBMCs) & [119] \\
\hline ASA-I & Alium sativum & IFN- $\gamma$ and IL-12 (murine spleen cells) & {$[30]$} \\
\hline KML & Viscum album var. coloratum & IL-12 (human dendritic cells) & [121] \\
\hline \multirow[t]{3}{*}{ ML-I } & \multirow[t]{3}{*}{ Viscum album } & IL-12 (human PBMCs) & {$[11]$} \\
\hline & & IL-15 (human neutrophils) & [122] \\
\hline & & IL-6, TNF- $\alpha$, and IL-10 (human PBMCs) & {$[123]$} \\
\hline PAA & Pisum arvense & IFN- $\gamma$ (murine spleen cells) & {$[75]$} \\
\hline PHA & Phaseolus vulgaris & IFN- $\gamma$ and IL-2 (murine spleen cells) & {$[25]$} \\
\hline PSA & Pisum sativum & IFN- $\gamma$ and IL-2 (murine spleen cells) & {$[25]$} \\
\hline PWM & Phytolacca americana & TNF- $\alpha$, IL-12, and IL-6 (human PBMCs) & [124] \\
\hline ScLL & Synadenium carinatum & IFN- $\gamma$ and IL-10 (murine bronchoalveolar lavage fluid-BALF) & {$[33]$} \\
\hline UEA-1 & Ulex europaeus & IL-2 and IFN- $\gamma$ (mice spleen) & {$[41]$} \\
\hline WGA & Triticum vulgaris & IL-12 and IFN- $\gamma$ (murine spleen cells) & {$[25]$} \\
\hline
\end{tabular}


be type-2 ribosome-inactivating protein (RIP). The B-chain selectively binds to $\beta$-galactosides [3], whereas the A-chain catalyzes hydrolysis of the N-glycosydic bond at adenine4324 in the eukaryotic $28 \mathrm{~S}$ ribosomal RNA, thereby inhibiting the elongation step of protein biosynthesis [4]. ML-I was identified as the active component of the Viscum album extract and is applied as a complementary treatment of cancer patients [5]. The ML-I B-chain binds to glycans on the surface of cancer cells and allows A-chain entry into the cytoplasm, where the latter chain is enzymatically active and highly cytotoxic. In vitro and in vivo studies have shown that the antitumor effects of ML-I are not only cytotoxic, but also immunomodulatory [6], an activity that is fundamental to its antitumor properties [7] (reviewed by Bocci, 1993 [8]). The cloning of the mistletoe lectin gene and the separate heterologous expression of the single chains $[9,10]$ have pointed out that the B-chain is responsible for the immunostimulatory activity of ML-I, mainly manifested by augmented IL-12 production and increased cytokine-induced Natural Killer Cells activation [11]. Comparison of the biological activities of the recombinant Mistletoe lectins (rML) -heterodimer [10] with those of some ML-I mutants [12] revealed a close correlation between cytotoxicity, apoptosis, and the enzymatic activity of the rML A-chain. Both the enzymatic activity exerted by the A-chain and the carbohydrate binding activity elicited by the B-chain are essential for the ML-I effect as an anticancer agent. The first step in the biological action of ML is to recognize and bind to specific ligands on the surface of target cells. Determination of the sugar specificity of ML has shown that this lectin preferentially binds to $\beta$-galactosides in the oligosaccharides of glycoproteins $[6,13,14]$. ML-I has a broad range of affinity for Gal $\alpha$ - and Gal $\beta$-linked sequences, revealing primary recognition of the terminal galactose unit irrespective of the anomeric linkage $[15,16]$. Recent studies on the binding specificity of ML-I toward glycosphingolipids and gangliosides have demonstrated its preferential binding to terminally $\alpha 2-6$-sialylated neolacto-series gangliosides isolated from human granulocytes, whereas rML only marginally binds to neutral gangliosides with terminal galactose moiety. Therefore, ML-I is a type-2 RIP, specific to sialic acid rather than galactose [17]. Indeed, gangliosides and glycoproteins with terminal Neu5Ac $\alpha 2-6 \mathrm{Gal} \beta 1-4 \mathrm{GlcNAc}$ residues are the true and physiologically relevant targets of ML-I recognition on the cell surface [18]. CD $75 \mathrm{~s}$ has glycans with terminal $\alpha 2-$ 6-sialyl-lactosamine and is an important target for rML recognition. It is expressed predominantly on activated B-cell, Tcell, and immature dendritic cells, and it is upregulated in hematological cancers along with the cells of solid tumors. As CD75s is overexpressed in solid tumors, these tumors have been the focus of preclinical trials for the efficacy of rML administration. More than $30 \%$ of the patients were observed to have stabilization in tumor progression associated with increased plasma levels of IL- $1 \beta$ and IFN- $\gamma$ in response to rML administration. The high IFN- $\gamma$ response indicates that $\mathrm{rML}$ administration stimulates Th1 cells, which may mediate an antitumor T-cell response (reviewed by Zwierzina et al. [19]).

Besides the European mistletoe, extracts of the Korean and Chinese mistletoes (Viscum album coloratum and Viscum articulatum, respectively) contain type-2 RIPs that bind Dgalactose $[20,21]$ and have high structural homology with ML. Like ML-I, they are endowed with immunomodulatory properties, as demonstrated by in vitro and in vivo studies. The B-chain of the Korean mistletoe lectin (KML) accounts for its immunomodulatory and antitumor activities. This is because the KML B-chain promotes NK cells activation and production of cytokines and inflammatory mediators by macrophages $[22,23]$. KML interaction with TLR-4 molecules is responsible for macrophage activation and cytokine production. Macrophages stimulation with KLM results in upregulation of TLR4 expression and enhanced TNF- $\alpha$ production, which is reduced by anti-TLR 4 specific antibodies or by assaying macrophages from TLR-4 deficient mice [24]. The recombinant Bchain of the Chinese mistletoe lectin (articulatin) stimulates human mononuclear cells to release TNF- $\alpha$ and IL-6 [21]. This suggests that the B-chain acts as an immunomodulator, like that of the European and Korean mistletoes.

Th1 immunity is induced by immunomodulatory plant lectins. As a rule, the Th1 immune response, manifested by high levels of IFN- $\gamma$ production, occurs through an IL-12dependent mechanism. In vitro assays with 12 different plant lectins have shown that six of the lectins induce murine spleen cells to produce IL-12 and IFN- $\gamma$ : Con A from Canavalia ensiformis, which binds to $\alpha$-linked mannose; PHA-E and PHA-L from Phaseolus vulgaris, which respectively bind to bisected bi- and tri-antennary complex N-glycans and highly branched non-bisected complex N-glycans); PSA from Pisum sativum, which binds to $\mathrm{N}$-glycans containing $\alpha$-linked mannose with an $\alpha$-fucose residue linked to $\mathrm{N}$-acetylchitobiose; and WGA from Triticum vulgaris, which binds to neuraminic acid and glycans containing terminal GlcNAc or GlcNAc $\beta 1$ 4GlucNAc [25]. Th1 cytokines production is induced by plant lectins such as ArtinM from Artocarpus heterophyllus [26], the Korean mistletoe lectin from Viscum album coloratum [27], Cramoll from Cratylia mollis [28], BanLec from Musa paradisiaca [29], and garlic lectin from Alium sativum [30]. Some of these lectins are able to induce Th1 cytokines upon interaction with glycosylated receptors on macrophages and/ or dendritic cells, such as type 2 and 4 Toll-like receptors (TLR2 and TLR4), respectively recognized by ArtinM [31] and KML [24]. Several plant lectins may act as TLR agonists [32]. The soybean (SBA), peanut agglutinin (PNA), ConA, and PHA lectins (PHA-L and PHA-P) stimulate extracellular TLRs $(2 / 6,4$, and 5), whereas WGA is pan-active.

Plant lectins can also regulate $\mathrm{Th} 2$ immunity. For example, mice receiving ScLL, a lectin from Synadenium carinatum with affinity for $\beta$-galactoside-containing glycans, exhibited 
lower leukocyte trafficking and Th2 cytokine production [34]. ScLL also reduced the pathological sequelae associated with the chronic inflammatory disease asthma in experimental animal models [33]. Th2 immunity can be induced by the lectin Bchain of type-2 RIP from Ricinus communis, which binds to Dgalactose containing glycans, including many glycoproteins expressed on the surface of enterocytes. This property motivated the genetic linking of the ricin B-chain with the coding region of the proinsulin gene, expressed as a fusion protein in E. coli [34] or in Solanum tuberosum (potato plant) [35]. Oral administration of this recombinant fusion protein to prediabetic NOD mice suppressed the auto-immune insulitis, associated with the Th2 immune response, whereas administration of insulin only did not interfere in the course of the disease [34]. The lectin interaction with glycans on the surface of enterocytes favors systemic tolerance to the fused autoantigen. Fusion proteins (immunomodulatory lectin/autoantigen) expressed in the tissues of edible plants provide a conceivable strategy to stimulate Th2 immunity and suppress autoimmunity.

Still regarding mucosal immunity, plant lectins that recognize glycans on the surface of $\mathrm{M}$ cells may favor mucosal immunity against orally administered antigens (reviewed by Azizi and cols. 2010 [36]). M cells express a particular glycosylation pattern on their surface, including L-fucosecontaining glycans [37], and transport a broad range of materials such as particulate antigens from the intestinal lumen to the underlying lymphoid tissue of the mucosae, where local and systemic potent immune response will be initiated. Ulex europaeus agglutinin (UEA-1) recognizes $\alpha$-L-fucose and selectively binds to the surface of murine $\mathrm{M}$ cells. This property explains why UEA-1 is the most studied lectin when enhanced potency of oral or nasal particulate vaccines is the ultimate target. UEA-1-poly-L-lysine coated on the surface of microparticles encoding HIV-1 genes was able to bind to the apical surface of $\mathrm{M}$ cells of mice immunized with these particles [38]. Both mucosal and systemic antibody (IgA and $\mathrm{IgG}$ ) and envelope-specific CTLs responses were augmented in mice immunized with poly-L-lysine conjugated to UEA1 and complexed to a plasmid encoding the HIV-1 envelope [39]. Oral immunization of mice with killed whole Helicobacter pylori or Campylobacter jejuni conjugated to UEA-1 induced protective responses against live challenge [40]. In a recent in vitro study, the hepatitis B surface antigen (HBsAg) encapsulated in liposomes coupled with UEA-1 predominantly targeted M-cells, in a sugar-dependent manner. In addition, the lectinized liposomes induced high sIgA level in mucosal secretions as well as high splenic levels of the IL-2 and IFN- $\gamma$ cytokines in orally immunized mice [41].

This overview provides basic information on plant lectins that act as immunomodulators. Although the text is not exhaustive, it shows that studies have mostly focused on the effects that these lectins may exert on cancer. On the other hand, our laboratory has extensively investigated the effects that a plant lectin, named ArtinM, may have on the course of experimental infections. This subject will be detailed in the subsequent sections of this review.

\section{ArtinM as an immunomodulatory lectin}

Immunomodulatory lectins may play critical roles in the response against infections. The immunobiological importance of carbohydrate recognition is patent in the literature. However, the role exerted by this kind of interaction in infectious diseases is much less appreciated than in other pathological circumstances, like cancer. One reason for the predominant investment in the study of protein-carbohydrate interactions in cancer is related to the logical impact of Hakomori's work, where the aberrant glycosylation pattern has been demonstrated in cancer cells thereby enhancing the biological significance of lectins [42]. This author described the aberrant glycosylation of cancer cells, rendering this subject the favourite for studies on the biological roles of lectins. The most relevant publications on this subject have already been approached in the first section of this review. A second reason for the focus on cancer may be the lack of detailed information on biologically relevant assays to understand the role of carbohydrate-lectin interactions in the immune system during infections.

Our research group is interested in the biological repercussions of carbohydrate recognition by animal [43, 44], pathogen [45-47], and plant lectins [48, 49], with particular emphasis on plant lectins extracted from Artocarpus heterophyllus (jackfruit) seeds. Our first study in this field involved Jacalin. This Gal/GalNAc-binding lectin is able to selectively bind to human IgA1 through recognition of the $\mathrm{O}$-glycan core, which is repeatedly found in the hinge region of the $\alpha 1$ heavy chain $[50,51]$.

The structural characterization of Jacalin raised a new key in lectin classification. The Jacalin-Related Lectins (JRL) were initially featured as having a $\beta$-barrel three-dimensional structure. The JRL were subsequently identified to be having two subfamilies of lectins, namely the Gal-specific JRLs and the Man-specific JRLs. Gal-specific homologs of Jacalin exist in the seeds of Artocarpus species [50] and Osage orange (Maclura pomifera) [52]. Man-specific JRLs have been isolated from species belonging to a wide range of taxonomic groups, including hedge bindweed (Calystegia sepium, family Convolvulaceae) [53, 54], Jerusalem artichoke (Helianthus tuberosus, family Asteraceae) [55], jackfruit (Artocarpus heterophyllus, family Moraceae) [49], rice (Oryza sativa, family Gramineae) [56], banana (Musa acuminata, family Musaceae) [57], Japanese chestnut (Castanea crenata, family Fagaceae) [58], faveira (Parkia platycephala, family Fabaceae) [59], and oilseed rape (Brassica napus, Brassicacea) [60]. Concomitant occurrence of Gal- and Man-specific JLRs has been reported 
Table 2 ArtinM biological properties

\begin{tabular}{|c|c|c|c|c|}
\hline Cell type & Glycotarget & Triggered events & Final effect & Reference \\
\hline Neutrophil & $\begin{array}{l}\text { N-Glycans on CXCR2 (on the } \\
\text { cell surface) and laminin (in } \\
\text { the extracellular matrix) }\end{array}$ & $\begin{array}{l}\text { (i) Signal transduction via G protein; (ii) } \\
\text { tyrosine phosphorylation; (iii) increased } \\
\text { TLR2 expression; (iv) release of leukotriene } \\
\text { B4 and CXCL8; (v) shedding of L-selectin; } \\
\text { (vi) superoxide production; (vii) phagocytic } \\
\text { activity enhancement. }\end{array}$ & $\begin{array}{l}\text { Cell activation and haptotaxis; } \\
\text { enhancement of effector functions }\end{array}$ & $\begin{array}{l}{[125,126]} \\
{[49]} \\
{[127,128]}\end{array}$ \\
\hline Mast cell & N-Glycans on Fce receptor & $\begin{array}{l}\text { (i) Cell degranulation; (ii) TNF- } \alpha \text { release; } \\
\text { (iii) mast cell recruitment from bone marrow }\end{array}$ & $\begin{array}{l}\text { Cell recruitment and degranulation; } \\
\text { contributes to neutrophil attraction }\end{array}$ & {$[117,129]$} \\
\hline Macrophage & N-Glycans on TLR2 & $\begin{array}{l}\text { (i) Signal transduction via MyD88; (ii) NF-kB } \\
\text { activation; (iii) IL-12 production }\end{array}$ & Th1 immunity & $\begin{array}{l}{[26,31]} \\
{[74]}\end{array}$ \\
\hline Dendritic cell & N-Glycans on TLR2 & $\begin{array}{l}\text { (i) Increased MHCII, CD80, and CD86 } \\
\text { expression; (ii) IL-12 production }\end{array}$ & Cell maturation and Th1 immunity & {$[75]$} \\
\hline
\end{tabular}

for two plant species only. One is the bark of the black mulberry tree (Morus nigra), which accumulates high concentrations of a Gal-specific JRL (called MornigaG) and a Manspecific homolog (called MornigaM) [61]. The other Artocarpus heterophyllus, seeds of which contain Jacalin, that binds Dgalactose and ArtinM that binds to D-mannose. In this review, we will focus on ArtinM.

ArtinM, also known as Artocarpin or $\mathrm{KM}^{+}$[62], specifically recognizes the trisaccharide $\operatorname{Man} \alpha 1-3$ [Man $\alpha 1-6]$ Man core of $\mathrm{N}$-glycans. Interaction of ArtinM with some $\mathrm{N}$-glycans on the cell surface activates innate-immunity cells, such as neutrophils, mast cells, dendritic cells, and macrophages. In this way, ArtinM administration protects against experimental infection with Leishmania spp and Paracoccidioides brasiliensis. The resistance conferred by ArtinM is attributed to recognition of N-glycans in the ectodomain of Toll-like receptors (TLR) expressed on the surface of innate-immunity cells, and the consequent induction of interleukin 12 (IL-12) production and development of the Th1 adaptive immune response (Table 2).

Here, we review the immunomodulatory effect of ArtinM and the mechanisms behind it. We describe murine experimental models of infection and detail its potential therapeutic applications against certain intracellular pathogens.

\section{ArtinM features}

ArtinM is a homotetramer consisting of $13-\mathrm{kDa}$ subunits. The primary structure of ArtinM comprises a polypeptide chain of 149 amino acids that shares $52 \%$ identity with the Jacalin sequence [63]. The differences between Jacalin and ArtinM are attributed to the absence of internal post-translational cleavage in ArtinM, which preserves a short glycine-rich linker sequence holding the regions analogous to the Jacalin $\alpha$ - and $\beta$-chains together [63]. These noncovalently associated Jacalin chains are constituted of 133 and 20 residues, respectively [64], which derive from a $17 \mathrm{kDa}$ precursor [65], whose cleavage does not occur in ArtinM molecule.

The three-dimensional structure of each monomer corresponds to a $\beta$-barrel, with a $\beta$-prism folding (Fig. 1). Each unit has a carbohydrate-recognition domain (CRD) that binds to $\mathrm{D}-$ mannose. ArtinM is thus a tetramer with four CRDs [63]. The structure of ArtinM complexes showed that CRD contains the ligand mannotriose. So, the lectin possesses a deep-seated binding site formed by three peptide loops (residues 14-17, 137-141, and 88-95). This binding site comprises two subsets, the primary and secondary sites. Interactions at the primary site, corresponding to two of the loops (residues 14-17 and 137-141), involves hydrogen bonds mainly. The secondary site is composed by the third loop (residues 88-95) and establishes interactions that are primarily van der Waals' in nature.

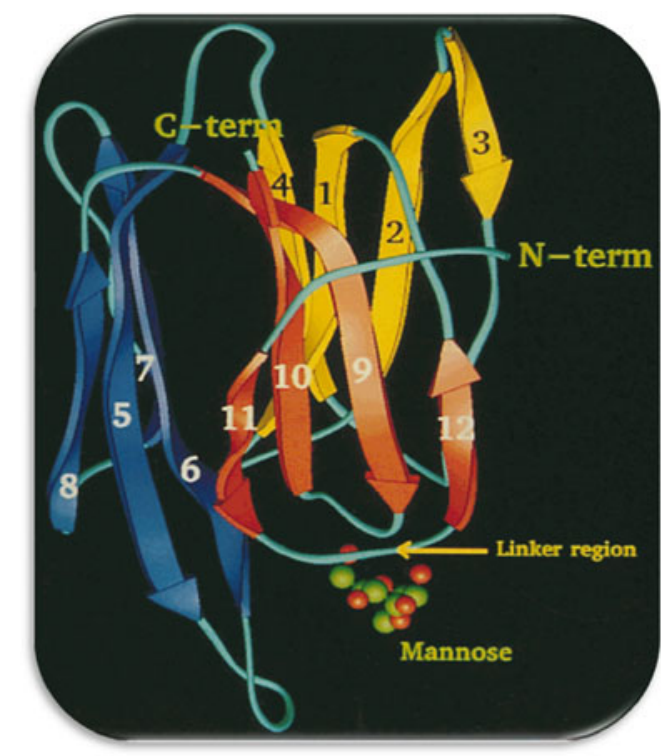

Fig. 1 Three-dimensional structure of the ArtinM monomer. Motifs are distinguished by color, and the positions of the mannose-binding site and linker region are indicated. (Authorized reproduction from Rosa et al. [63]) 
Mannotriose interacts through the three mannopyranosyl residues in its complex with the lectin; mannopentose interacts with the protein via at least three of the five mannose residues. The complexes provide a structural explanation for the carbohydrate specificities of ArtinM. A detailed comparison with the sugar complexes of Heltuba lectin, another mannose-specific JRL with known three-dimensional structure in the sugarbound form, has established that the sugar-binding loop constituting the secondary site has a role in the different specificities observed at the oligosaccharide level. This loop is four residues longer in the ArtinM CRD than in the Heltuba CRD, so variation in the loop length is a strategy to generate carbohydrate specificity [66].

Molecular modeling and crystallization studies have shown that structural differences account for the distinct carbohydrate-binding specificities between ArtinM and Jacalin $[63,66,67]$, especially with respect to the recognition of Dmannose, but not D-galactose, by ArtinM. The binding affinity of ArtinM for the glycoprotein horseradish peroxidase (HRP) is 1633-fold higher than that for the monosaccharide D-mannose. This is because ArtinM interacts with the trimannoside core of the HRP N-glycan, which is reinforced by binding to the mannosyl end of the branched oligosaccharide. The superposition of the mannosyl end with the trisaccharide in the complex leads to severe steric clashes involving the xylose residue and loops $86-95$ of the lectin. This results in eight hydrogen bonds and increased binding energy [66].

Although xylose appears to be responsible for the increase in binding energy, it adorns plant $\mathrm{N}$-glycans, as mentioned for HRP, but not mammalian N-glycans [68]. The saccharides that can be coupled to the core of mammalian $\mathrm{N}$-glycans are GlcNAc or Fuc and both are able to establish many van der Waals contacts with loop residues 87-93 of ArtinM [66]. Glycoarray analysis of ArtinM specificity (unpublished data) revealed that subsets of complex-type bi-antennary N-glycans containing Man $\alpha 1-3(\operatorname{Man} \alpha 1-6) \operatorname{Man} \beta 1-4$ GlcNAc $\beta 1-$ $4 \mathrm{GlcNAc} \beta$ are well recognized by the lectin. The branch attached to Man $\alpha 1-6$ contributes to ArtinM recognition, whereas Man $\alpha 1-3$ elongation reduces lectin binding. A previous study of ArtinM specificity evidenced enhanced recognition of $\alpha 1$-6Man-extended compared with $\alpha 1$-3Man-extended mono-antennary glycans [69]. This unusual binding mechanism accounts for the selectivity of ArtinM binding to certain $\mathrm{N}$-glycans, such as those linked to some protein cell receptors.

\section{Recombinant ArtinM}

ArtinM has potential pharmaceutical applications. However, evaluation of these uses has been limited by the lectin paucity in the extract of $A$. heterophyllus seeds (less than $0.5 \%$ of the total protein content) [49]. To further explore the properties of ArtinM, its cDNA has been cloned and heterologously expressed in Saccharomyces cerevisiae and Escherichia coli [70].

Glycoarray analysis of ArtinM has shown that the native (ArtinM) and recombinant (rArtinM) forms display the same specificity for Man $\alpha 1-3(\operatorname{Man} \alpha 1-6) \operatorname{Man} \beta 1-4$ in the context of N-Glycans. Electrogravimetric analysis, allied to a simple kinetic model for HRP binding to the native and recombinant forms of ArtinM, established equivalence for the kinetics of binding/association affinity of the ligand sites [71]. Therefore, ArtinM CRD is preserved in rArtinM, thus facilitating study of its biological properties.

rArtinM reproduces the biological properties of ArtinM, including neutrophil chemotaxis and mast cell degranulation (unpublished data). IL-12 production also occurs when murine macrophages [72] are treated with native or recombinant forms of ArtinM. In addition, the recombinant form is able to induce the release of other inflammatory products, such as TNF- $\alpha$ and NO, at the same level as the native form (unpublished data). Besides the in vitro analysis, the ArtinM immunomodulatory effect was reproduced by rArtinM in an assay involving a model of systemic fungal disease caused by Paracoccidioides brasiliensis. Administration of ArtinM or rArtinM to mice before or after fungal inoculation induced Th1 immunity, as attested by high TNF- $\alpha$ and IL-12 levels as well as low IL-4 concentrations. Compared with untreated controls, ArtinM- or rArtinM-treated animals exhibited minor pulmonary lesions and fungal burden [31].

\section{ArtinM targets TLR2 N-glycans to induce IL-12 production}

The first indication that ArtinM has an immunomodulatory property was its ability to induce IL-12 production by murine macrophages. This ability depends on the lectin concentration and CRD, and IL-12 production is selectively inhibited by D-mannose [26].

IL-12, a 70-kDa heterodimeric cytokine, is important for the activation of the type- 1 immune response. A bioactive IL-12p70 form comprises two disulfide-linked subunits: a heavy 40-kDa chain (p40) and a light 35-kDa chain (p35). Macrophages and dendritic cells are the major producers of this cytokine, which is released as a biologically inactive (IL-12p40) and also as a biologically active form (IL-12p70) [73]. IL-12 acts on T lymphocytes and natural killer (NK) cells, and it induces IFN- $\gamma$ production (Figs. 2 and 5). This hallmark Th1 cytokine functions on $\mathrm{T}$ cell proliferation and enhances the cytotoxic activity of macrophages.

By inducing IL-12 production, ArtinM promotes a protective Th1-type response against intracellular pathogens $[26,74,75]$. Reversion of its beneficial effect on IL-12 genetically deficient mice demonstrated the crucial role of IL-12 in the resistance conferred by ArtinM [74]. IL-12 


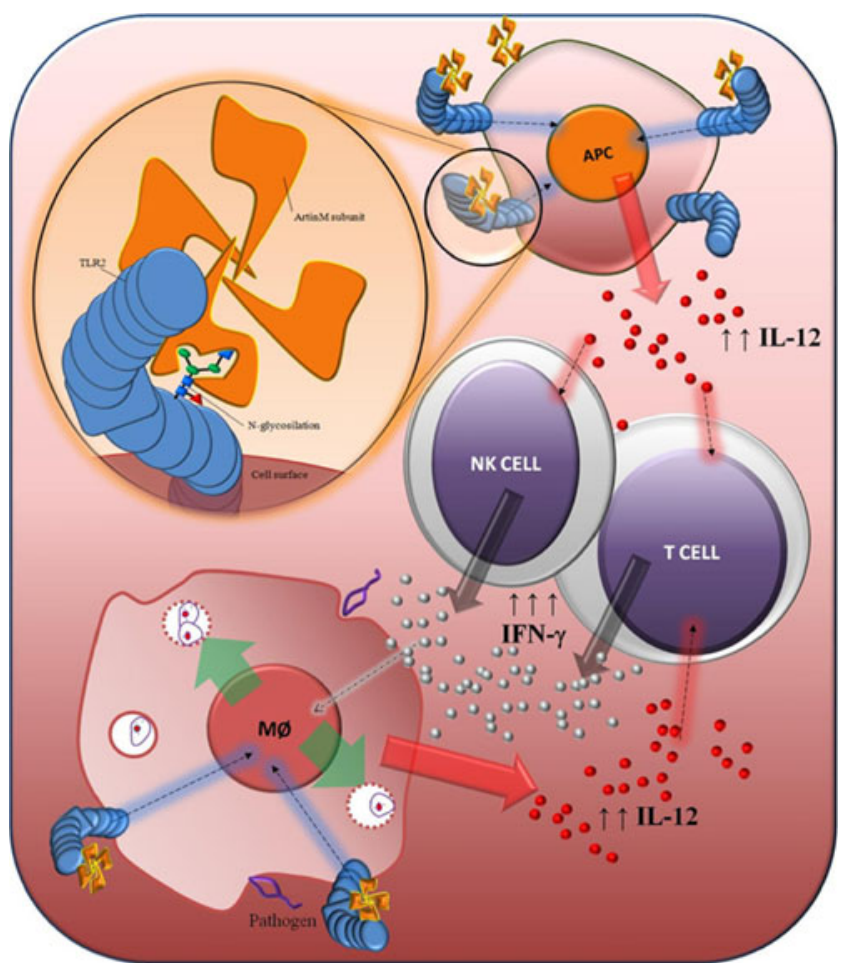

Fig. 2 Immunological repercussions of ArtinM binding to antigenpresenting cells (APCs). The interaction of ArtinM with TLR2 Nglycans on APCs promotes IL-12 production. This cytokine induces increased IFN- $\gamma$ production by natural killer (NK) and/or T cells, shaping a Th1 immune response. IFN- $\gamma$ increases the microbicidal activity of macrophages. ArtinM stimulation of infected macrophages further increases the release of IL-12, constituting an amplification looping of Th1 immunity against intracellular pathogens

production by phagocytes is generally initiated by interaction of cell-surface TLR with pathogen-associated molecular patterns (PAMPs).

Toll-like receptors play a key part in the initiation of innate immune responses against pathogens in mammals. Moreover, they recognize a variety of PAMPs from bacteria, viruses, and fungi [76]. To date, more than a dozen different TLRs have been identified. TLRs 1-9 are conserved in humans and mice, TLR10 is selectively expressed in humans, and TLR11 is functional in mice [77]. TLRs are type-I transmembrane proteins. Their ectodomains contain leucine-rich repeats that mediate PAMP recognition. Downstream signal transduction requires their intracellular Toll-IL-1 receptor (TIR) domains. Studies on mice deficient in different TLRs have demonstrated that each TLR has a distinct function in terms of PAMP recognition and immune-response induction [78]. This finding opens new frontiers in the development of therapeutic strategies, as attested by the use of a TLR agonist (Box 1).

Amino acid sequencing analysis of all of the TLRs identified to date has revealed the presence of potential N-linked glycosylation sites. Several lines of evidence indicate that oligosaccharides attached to TLRs play important roles in PAMP recognition and in the formation of a functional receptor complex on the cell surface [79-83]. The ectodomain of human TLR2 contains Nglycans linked to residues Asn114, Asn199, Asn414, and Asn442; the glycan at Asn442 contributes to efficient secretion of the TLR2 ectodomain [80] and PAMP recognition [84].

We have established that ArtinM-induced IL-12 production occurs via recognition of TLR2 $\mathrm{N}$-glycans (unpublished data) (Fig. 2), but not TLR4 N-glycans; only macrophages from TLR2-deficient mice failed to produce IL-12 in response to ArtinM stimulus [74]. Notably, the ability of ArtinM to induce IL-12 production in wild type (WT) cells was selectively blocked by D-mannose. A gene report assay using TLR2-transfected cells demonstrated direct interaction of ArtinM with TLR2 (unpublished data). The fact that the TLR2 ectodomain contains $4 \mathrm{~N}$-glycans further evidenced TLR2 targeting by ArtinM. We are currently working to identify which glycan(s) is (are) targeted by ArtinM using TLR2 mutants for the ectodomain glycosylation sites (generated in Dr. Nicholas Gay's laboratoryDepartment of Biochemistry, University of Cambridge).

\section{ArtinM signaling induces IL-12 production and ArtinM affects dendritic cell (DCs) maturation}

The TLR signaling triggered by PAMP recognition frequently involves the adaptor molecule and the myeloid differentiation primary response gene MyD88, and this signaling induces nuclear factor- $\mathrm{kB}$-dependent cytokine production $[85,86]$. The signaling triggered by interaction of TLR2 glycans with ArtinM, which accounts for IL-12 induction (Figs. 2 and 5), also requires the MyD88 adaptor molecule [74]. Indeed, macrophages from animals deficient in MyD88 failed to produce IL-12 under ArtinM stimulation. Detection of luciferase activity following ArtinM stimulation confirmed NF- $\mathrm{KB}$ activation in a gene report assay using HEK293 cells transfected with TLR2 and NF-KB luciferase (manuscript in preparation).

ArtinM also stimulates dendritic cells to produce IL-12 via TLR2 recognition (unpublished data). Indeed, ArtinM induces maturation of bone marrow-derived dendritic cells (BMDC), as manifested by a higher expression of MHC class II, CD80, and CD86 molecules, which characterizes a profile of mature DCs, capable of priming T cells (Table 2).

\section{Investigation of ArtinM-induced Th1 immunity in the murine model of Leishmania infection}

Leishmaniasis is a complex of diseases caused by protozoan parasites of the genus Leishmania, with high impact on 
Box 1. TLR agonist

There are consistent reasons for targeting TLR as an alternative therapeutic agent.
Currently, imiquimod is the most frequently used TLR ligand in clinical practice. It
has been approved for the treatment of external genital warts and (pre-)cancerous skin
lesions, such as actinic keratoses and superficial basal cell carcinoma. Upon topical
application, this TLR7 agonist induces increased IFN-a, IL -12, and TNF-a
production, shaping a Th1-prone immune response. Imiquimod enforces the
recruitment of myeloid and plasmacytoid dendritic cells and cytotoxic T cells, and it
enhances the ability of antigen-presenting cells to induce reactive T cells. These
multifaceted actions, which comprise proapoptotic, antifibrotic, antiangiogenic, and
antiaging effects, provide efficacy to the treatment of various other skin diseases
(reviewed by Novak et al. [130]). In contrast to new adjuvants (comprising complex
mixtures of emulsions, detergents, and immunostimulatory components), the
interaction of miquimod with TLR-7 provides a well-defined cellular target and
signaling, which can rationally enhance the adjuvant potency of vaccines; e.g.,
against Plasmodium falciparum [131]or the treatment of cutaneous leishmaniasis
[132,133]. Other new TLR-agonists, designed through variations of structures and
synthetic stimulatory motifs, can be used to modulate immunity and develop novel
drugs that are quite distinct from natural ligands. The ability to modulate immune
responses in a desired and optimal fashion may facilitate the targeting of a broad
range of diseases, including cancer, asthma, allergies, and infections. Viral and
synthetic ssRNAs act as agonists of TLR7 and TLR8. Certain nucleoside analogs,
such as loxoribine, 7-thia-8-oxo-guanosine, and 7-deazaguanosine, activate TLR7.
Imidazoquinoline-based compounds act as agonists of TLR7 and TLR8, and they
interact with adenosine-receptor signaling pathways to induce immune responses.
Bacterial and synthetic DNA containing unmethylated CpG motifs act as agonists of
leinasinalis [135].

public health in many regions worldwide. Leishmania multiplies within mononuclear phagocytic system cells. Depending upon the parasite species and host immune response, the infection causes a wide spectrum of clinical manifestations, including self-healing single-skin, mucosal, and diffuse cutaneous lesions. The disease also manifests as a severe systemic infection called visceral leishmaniasis, with liver and spleen enlargement, cachexia, and persistent fever (reviewed by Brodskyn et al. [87]). The clinical signs have been attributed to the ability of the parasite to spread to lymphatic and hematogenic pathways [88, 89]. Parasite persistence in the tissues accounts for the damage [90].

Severity of non-healing cutaneous lesions, persistence of parasites at the inoculation site, and scattering by organs such as the liver and spleen [91] constitute signs of susceptibility to leishmaniasis, which is associated with the immune-response profile the host develops. This relationship has been extensively investigated in murine models of leishmaniasis, which showed different degrees of susceptibility depending on the infected mouse strain. In this context, BALB/c mice are susceptible to $L$. major infection, while $\mathrm{C} 57 \mathrm{BL} / 6$ mice are resistant and able to mount an effective immune response against the parasite [92]. Infection of susceptible BALB/c mice by L. major is an established leishmaniasis model and has contributed to characterization of the dichotomy of the T helper 1 (Th1) and $\mathrm{T}$ helper 2 (Th2) profile responses [93, 94], showing that resistance and susceptibility are caused by the 
appearance of parasite-specific $\mathrm{CD} 4^{+} \mathrm{Th} 1$ or $\mathrm{CD} 4^{+} \mathrm{Th} 2$ cells, respectively. Infected $\mathrm{BALB} / \mathrm{c}$ mice display strong IL-4 and IL-10 mRNA expression and very low IFN- $\gamma$ mRNA expression, whereas infected C57BL/6 animals exhibit high IFN- $\gamma$ and IL-10 mRNA levels [95]. Thus, during the early stages of infection, resistance is associated with IFN- $\gamma$ production, whereas susceptibility is linked to IL-4 production [96].

We have demonstrated that ArtinM administration elicits IFN- $\gamma$ secretion by murine spleen cells. We have taken advantage of the well-established model of susceptibility of $\mathrm{BALB} / \mathrm{c}$ mice to L. major infection and determined whether the IL-12 production induced by ArtinM could reverse the $\mathrm{Th} 2$ response that is itself responsible for severe manifestations of the infection. Compared with untreated mice, mice pre-treated with ArtinM (3 doses of $0.5 \mu \mathrm{g}$ ) in combination, or not, with soluble L. major antigens (SLA) and challenged with $1 \times 10^{6}$ promastigotes of $L$. major had smaller lesions (Fig. 3). Association of ArtinM-pretreatment with anti-IL-12 administration blocked the beneficial effect of ArtinM on the foot lesion. This reinforced that ArtinM acts by changing the pattern of cytokine production, as confirmed by the concentration of cytokines produced by the lymph node cells draining the site of parasite inoculation in mice. Cells from SLA-injected animals released high IL-4 and low IFN- $\gamma$ concentrations. In contrast, cells from animals injected with Artin-M produced lower IL-4 and higher IFN- $\gamma$ concentrations. Thus, Artin-M stimulates a drive toward Th1 response in vivo, contrary to the IL-4-driven, polarized Th2 cell response found for the model of a nonhealing L. major infection in BALB/c mice.

$\mathrm{BALB} / \mathrm{c}$ mice immunized with $0.5 \mu \mathrm{g}$ of ArtinM and challenged with $L$. amazonensis $\left(1 \times 10^{6}\right.$ infective-stage promastigotes) exhibited significant reduction in the number of

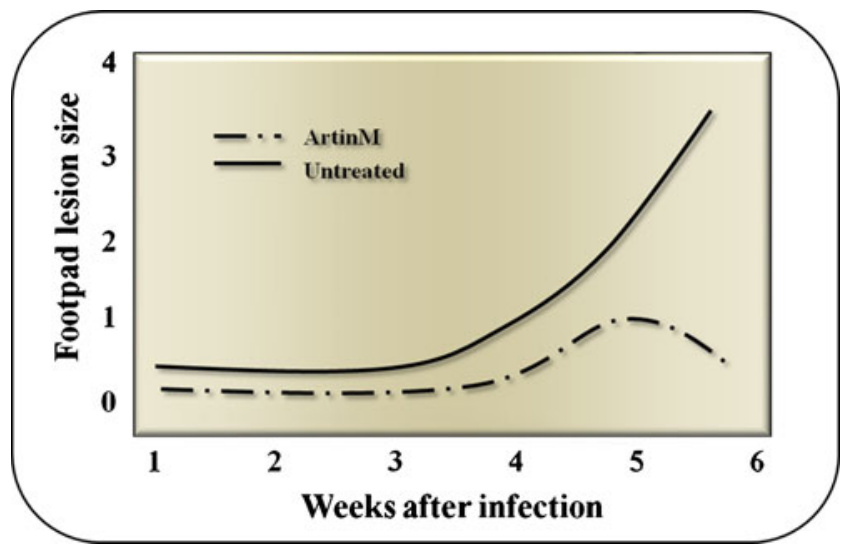

Fig. 3 ArtinM administration avoids the footpad lesion caused by $L$. major inoculation in BALB/c mice. Mice were administered with ArtinM $(10 \mu \mathrm{g} / \mathrm{mL})$ or vehicle (PBS) and infected (in the hind footpads) with $1 \times 10^{6}$ metacyclic promastigotes of $L$. major. The evolution of the lesion was assessed by measuring the footpad thickness, during an 8-week period. Modified of Panunto-Castelo et al. [26] parasites (48\%), and this decrease was even greater $(80 \%)$ when ArtinM was associated with SLA [75]. IFN- $\gamma$ production significantly increased when splenic cells from BALB/c mice were stimulated with ArtinM in vitro. Hence, ArtinM was able to control $L$. amazonensis infection, probably by acting upon initial immune response.

The murine models of Leishmania infection provide strong evidence for the immunomodulatory effect of ArtinM toward a Th1 profile. They also indicate the importance of induced IL-12 production for the protection conferred by ArtinM against Leishmania spp, reinforcing the in vitro results described in section "ArtinM targets TLR2 N-glycans to induce IL-12 production".

\section{ArtinM-induced Th1 immunity confers protection against a fungal disease}

Our research on the effect of ArtinM on experimental leishmaniasis motivated us to evaluate how this lectin interferes with the course of other infection for which host resistance depends on the Th1 response. We chose to investigate the experimental model of paracoccidioidomycosis (PCM), which is the most frequent human systemic mycosis in Latin America, and for which a favorable outcome is associated with early and sustained IFN- $\gamma$ production.

PCM is caused by the dimorphic fungus Paracoccidioides brasiliensis and is characterized by lesions in the lungs, lymph nodes, skin, and mucous membranes (oral, nasal, and gastrointestinal) [97]. Infection occurs after inhalation of airborne conidia produced by the mycelial form of the fungus. In the lungs, at $37{ }^{\circ} \mathrm{C}$, the inhaled forms are transformed into yeasts, which cause pulmonary granulomatous lesions and can disseminate to many organ systems via the bloodstream and/or lymphatic system [98, 99]. Depending on the hostspecific immunity and virulence of the infecting agent, the infection results in a wide spectrum of clinical manifestations. These range from a few localized forms to systemic infection of multiple organs and, eventually, severe and even fatal disease [100].

Although the mechanisms involved in resistance to $P$. brasiliensis are still poorly understood, there are clinical and experimental evidences that the cell-mediated immune response plays an important role in host defense against PCM [101-103]. The Th1 immune response exerts a singular role in the asymptomatic form of PCM, while a Th2 pattern is associated with the development of severe disease [104-106]. Resistance and susceptibility to fungal infections have been studied in murine models of infection, which simulate the human mycosis. These models have furnished details of the immune response mechanisms involved in PCM. Resistant 
mice produce early and sustained IFN- $\gamma$ and IL-2 levels, whereas susceptible mice produce low IFN- $\gamma$ but significant IL-5 and IL-10 levels [107, 108]. IFN- $\gamma$ activates TNF- $\alpha$ secretion and fungal replication inhibition by infected macrophages. TNF- $\alpha$, in turn, is required for macrophage accumulation and granuloma formation in the lungs of $P$. brasiliensisinfected mice. Infected mice treated with anti-IFN- $\gamma$ showed exacerbated pulmonary infection and early fungal dissemination [109]. The essential role of these cytokines has been further demonstrated by using mice genetically deficient in either the IFN- $\gamma$ or TNF- $\alpha$ receptor $[109,110]$. The functions of cytokines accounting for macrophage activation have been consistently documented and are necessary for fungal killing [111-113].

To investigate the interference of ArtinM administration in PCM, our group used an experimental model in which $1 \times 10^{6}$ yeast cells of a virulent $P$. brasiliensis isolate were intravenously inoculated into BALB/c mice. We evaluated infection severity by the intensity of pulmonary fungal burden and lesions, as well as the extension of fungal dissemination. A screening of regimens of ArtinM administration established that an effective therapeutic protocol consisted of a single subcutaneous injection of ArtinM, 10 days after infection, whereas administration of two subcutaneous injections of ArtinM, on day 10 and day 3 before infection, afforded the best prophylaxis. The therapeutic and prophylactic forms of ArtinM administration were associated with an important decrease in the colony-forming units (CFU) recovered from the mice lungs on day 30 after infection. The lungs presented only mild infiltration of mononuclear cells, contrasting with the lungs of untreated mice, which had multiple sites of focal and confluent epithelioid granulomas, with lymphomonocytic halos circumscribing a high number of viable and non-viable yeast cells (Fig. 4). On day 60 post infection, the untreated mice exhibited disseminated infection, as indicated by the confluent epithelioid granulomas in their liver and spleen. In contrast, infected mice administered with prophylactic or therapeutic ArtinM exhibited no granulomas or yeast cells in the pulmonary sections and had a well-preserved bronchoalveolar structure along with expected no fungal dissemination to the liver or spleen. Therefore, ArtinM exerted a beneficial effect on the severity of $P$. brasiliensis infection [31, 74, 114].

The advantageous effect of ArtinM administration correlates with an adequate milieu of pulmonary mediators. The lung homogenates from mice infected with $P$. brasiliensis and administered with prophylactic or therapeutic ArtinM showed higher levels of the pro-inflammatory cytokines IL12 and TNF- $\alpha$, and also of NO. In addition, lower IL-4 and higher IFN- $\gamma$ concentrations were stably produced during the disease course in ArtinM-treated mice, whilst high IL-4 and low IFN- $\gamma$ concentrations were detected in untreated control mice. As in the case of the Leishmania infection model, we concluded that a drive toward a Th1 response is stimulated in vivo by ArtinM. Besides that, we verified stable IL-10 production in the ArtinM-treated mice. Therefore, ArtinM administration correlates with the establishment of Th1 immunity, balanced by the presence of an anti-inflammatory cytokine (Fig. 5). Interestingly, we also observed, but did not report, IL-10 production in the BALB/ c mice infected with L. major and administered with ArtinM.

We have investigated the importance of IL-12 for the beneficial effects of ArtinM on experimental PCM. IL-12 knockout (KO) mice inoculated with the fungus and treated with ArtinM were not protected against the infection, showing the crucial nature of IL-12 is for the immunomodulatory effect exerted by ArtinM. We propose that ArtinM interferes with the outcome of P. brasiliensis infection, by modulating the host immunity against the fungus according to the following events: recognition of TLR2 glycans by the lectin; induction of IL-12 production (Fig. 2); generation of a Th1-balanced immunity; and protection against $P$. brasiliensis.

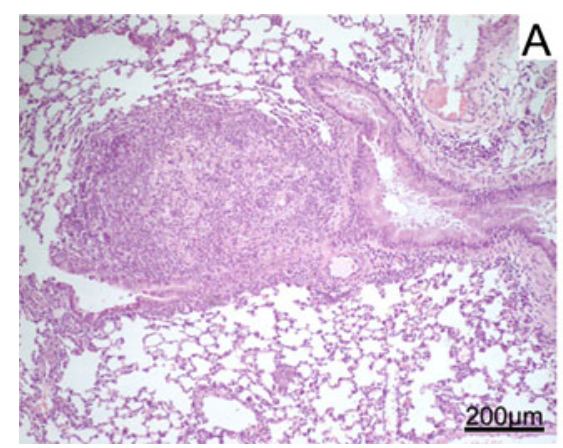

Fig. 4 Protective effect of ArtinM against P. brasiliensis infection. Untreated and ArtinM $(10 \mu \mathrm{g} / \mathrm{mL})$ treated BALB/c mice were intravenously infected with $1 \times 10^{6}$ virulent $P$. brasiliensis yeast cells. At the week 2 postinfection, the pulmonary tissue from untreated mice

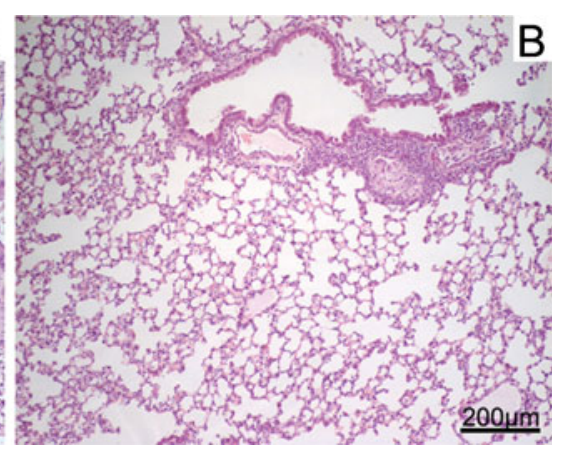

presented large granulomas surrounding a great number of yeast cells (a), while ArtinM treated mice showed small areas of mononuclear cells infiltration, in which few yeast cells were seen (b) 


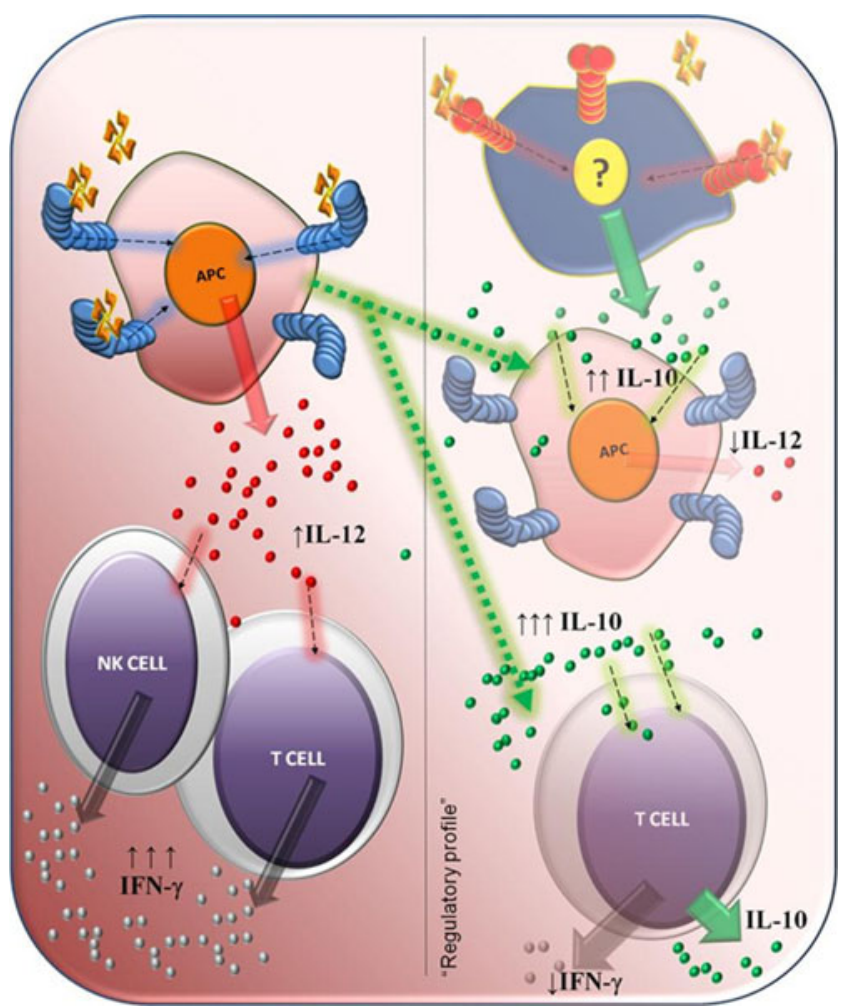

Fig. 5 Pleiotropic activity of ArtinM allows the construction of a Th1 immunity regulated by IL-10. ArtinM administration leads to the production of Th1 cytokines and IL-10, whereas no IL-4 is detected. The cell responding to ArtinM stimulus through IL-10 production has not yet been identified. IL-10 is assumed to counterbalance the inflammation associated with Th1 immunity, thereby preventing tissue injury

The parallel utilization of recombinant ArtinM to treat the P. brasiliensis-infected mice provided evidence that the administration of ArtinM or rArtinM has an equally protective effect against the infection. [31].
In conclusion, ArtinM exerts a protective effect against experimental infection with $P$. brasiliensis, leading to a Th1biased immune response with a direct beneficial effect on the severity of lung lesions. The mechanism of protection involves induction of endogenous IL-12, in a process dependent on the MyD88/TLR2 signaling pathway. The detection of IL-10 production in ArtinM-treated animals revealed that the induced Th1-prone immune response is regulated to prevent systemic immune pathology, as indicated by the absence of exacerbated inflammatory lesions in animals administered with ArtinM (Fig. 5). The identification of the cell source of IL-10 is under investigation, as part of a study of ArtinM pleiotropic activities (Box 2) $[115,116]$.

The new perspectives offered by ArtinM in the development of antifungal therapy has been reviewed recently [114].

\section{Additional interactions of ArtinM with immune cells account for its pleiotropic effects}

Pleiotropism refers to the ability of certain mediators, such as cytokines, to act on different cell types. It is an important property shared by all cytokines, and accounts for their ability to act on innate and also adaptive immunity. Various examples illustrate the pleiotropic activities of cytokines. IL-12 enhances NK cell cytotoxicity in innate immunity and induces Thl cell differentiation in adaptive immunity. IFN- $\gamma$, in turn, activates macrophages in the innate and also in the adaptative cell-mediated immune response. Moreover, it increases expression of MHC molecules and enhances antigen processing and presentation. IL-10 (which is produced by macrophages, some $\mathrm{T}$ helper cells, and mast cells) inhibits activated macrophages and dendritic cells,

Box 2. ArtinM exerts positive or negative control of Th17 immunity.

Several lines of evidence indicate that ArtinM pleiotropism is responsible for its
immunomodulatory effect against infection by intracellular pathogens such as $P$.
brasiliensis. The studies of Loures and coworkers [136] on the role of TLR2 in
pulmonary PCM give a rational basis to the hypothesis that ArtinM, as a TLR2 agonist,
can negatively control Th17 immunity and prevent tissue injury. This suggests the
existence of an additional mechanism for the beneficial effect of ArtinM
administration. However, a very recent study revealed that ArtinM induced Th17
immunity in a model of Candida albicans infection [137]. Further studies on the effect
of ArtinM on Th17 immunity are necessary.


decreases inflammation by inhibiting Th1 cells, and inhibits IL-12 release by macrophages. Although pleiotropism allows cytokines to mediate diverse effects, numerous undesirable side effects limit their therapeutic use. The biological characterization of ArtinM indicates its pleiotropism. As already mentioned, ArtinM activates a variety of cells by interacting with glycosylated receptors on their surface. In addition to the interaction with TLR2 glycans in macrophages and dendritic cells (which is responsible for IL12 production and induction of Th1 immunity), ArtinM activates neutrophils via recognition of $\mathrm{N}$-glycans linked to receptors such as CXCR2 and TLR2. This induces cell migration, release of inflammatory mediators, and enhancement of effector functions. ArtinM also targets glycosylated receptors on the surface of mast cells, which leads to cell degranulation; release of cytokines such as TNF- $\alpha$, IL-10, and IL-8; and recruitment and differentiation of mast cell precursors from the bone marrow. By analogy with the limitations found for the therapeutic use of cytokines, we are currently evaluating whether the pleiotropic effects of ArtinM impair its immunomodulatory activity. Preliminary results suggest that the pleiotropic effects of ArtinM are not harmful in our models of infection; in fact, neutrophil activation induced by ArtinM appears to favor elimination of intracellular pathogens without causing exacerbated inflammation. We hypothesize that the potential pro-inflammatory effects of ArtinM are counterbalanced by its ability to induce IL-10 production, and we are currently investigating the cell source of this cytokine.

\section{Conclusions and future directions}

In this review, we have focused on the immunomodulatory properties of ArtinM. We have provided a structural basis of sugar recognition by ArtinM and applied our knowledge of lectin specificity to explain its interaction with glycosylated receptors on the cell surface. We specifically studied the interaction of ArtinM with TLR2 N-glycans on the surface of macrophages and dendritic cells, because this interaction is primarily responsible for the immunomodulatory activity of this lectin. This activity is characterized by induction of IL-12 production, development of Th1 immunity, and ability to confer protection against murine infections with intracellular pathogens, such as Leishmania spp and P. brasiliensis. We compared the immunomodulatory activity of ArtinM with those triggered by TLR agonists and considered the former lectin to be advantageous, because of its pleiotropic feature. The presence of multiple glycan targets of ArtinM on the surface of different cells (including neutrophils, macrophages, dendritic cells, and mast cells) appears to favor efficient immunomodulation. However, many questions remain to be answered. We are currently working on: (i) determining the specificity of ArtinM toward complex glycans; (ii) identifying cell-surface receptors through which N-glycans are recognized by ArtinM; (iii) extending the range of animal models used to assay the effects of ArtinM immunomodulatory activity; (iv) evaluating ArtinM immunomodulatory activity during the early phases of acute infections; and $(v)$ understanding the mechanisms responsible for the ArtinM immunomodulatory activity.

Acknowledgments We thank Dr Constance Oliver and Dr. Ademilson Panunto Castelo for comments on the manuscript and Dr Els Van Damme for reviewing the final version of the manuscript and supporting its submission as a member of Editorial Board of the Glycoconjugate Journal. Preparation of this manuscript was supported by grants number 2006/60642-2 from Fundação de Amparo a Pesquisa do Estado de São Paulo (FAPESP) and Conselho Nacional de Desenvolvimento Científico e Tecnológico (CNPq).

Open Access This article is distributed under the terms of the Creative Commons Attribution License which permits any use, distribution, and reproduction in any medium, provided the original author(s) and the source are credited.

\section{References}

1. Van Damme, E.J.M., Peumans, W.J., Barre, A., Rougé, P.: Plant lectins: a composite of several distinct families of structurally and evolutionary related proteins with diverse biological roles. Crit. Rev. Plant Sci. 17(6), 575-692 (1998)

2. Van Damme, E.J.M., Lannoo, N., Peumans, W.J.: Plant Lectins. Adv. Bot. Res. 48, 107-209 (2008)

3. Olsnes, S., Stirpe, F., Sandvig, K., Pihl, A.: Isolation and characterization of viscumin, a toxic lectin from Viscum album L. (mistletoe). J. Biol. Chem. 257(22), 13263-13270 (1982)

4. Endo, Y., Tsurugi, K., Franz, H.: The site of action of the A-chain of mistletoe lectin I on eukaryotic ribosomes. The RNA Nglycosidase activity of the protein. FEBS Lett. 231(2), 378-380 (1988)

5. Klopp, R., Schmidt, W., Werner, E., Werner, M., Niemer, W., Beuth, J.: Influence of complementary Viscum album (Iscador) administration on microcirculation and immune system of ear, nose and throat carcinoma patients treated with radiation and chemotherapy. Anticancer. Res. 25(1B), 601-610 (2005)

6. Hajto, T., Hostanska, K., Gabius, H.J.: Modulatory potency of the beta-galactoside-specific lectin from mistletoe extract (Iscador) on the host defense system in vivo in rabbits and patients. Cancer Res. 49(17), 4803-4808 (1989)

7. Beuth, J., Ko, H.L., Gabius, H.J., Pulverer, G.: Influence of treatment with the immunomodulatory effective dose of the beta-galactoside-specific lectin from mistletoe on tumor colonization in BALB/c-mice for two experimental model systems. In Vivo 5(1), 29-32 (1991)

8. Bocci, V.: Mistletoe (viscum album) lectins as cytokine inducers and immunoadjuvant in tumor therapy. A review. J. Biol. Regul. Homeost. Agents 7(1), 1-6 (1993)

9. Eck, J., Langer, M., Mockel, B., Baur, A., Rothe, M., Zinke, H., Lentzen, H.: Cloning of the mistletoe lectin gene and characterization of the recombinant A-chain. Eur. J. Biochem. / FEBS 264 (3), 775-784 (1999)

10. Eck, J., Langer, M., Mockel, B., Witthohn, K., Zinke, H., Lentzen, H.: Characterization of recombinant and plant-derived mistletoe lectin and their B-chains. Eur. J. Biochem. / FEBS 265 (2), 788-797 (1999) 
11. Hajto, T., Hostanska, K., Weber, K., Zinke, H., Fischer, J., Mengs, U., Lentzen, H., Saller, R.: Effect of a recombinant lectin, Viscum album agglutinin on the secretion of interleukin-12 in cultured human peripheral blood mononuclear cells and on NKcell-mediated cytotoxicity of rat splenocytes in vitro and in vivo. Nat. Immun. 16(1), 34-46 (1998)

12. Langer, M., Mockel, B., Eck, J., Zinke, H., Lentzen, H.: Sitespecific mutagenesis of mistletoe lectin: the role of RIP activity in apoptosis. Biochem. Biophys. Res. Commun. 264(3), 944-948 (1999). doi:10.1006/bbrc.1999.1610

13. Barbieri, L., Battelli, M.G., Stirpe, F.: Ribosome-inactivating proteins from plants. Biochim. Biophys. Acta 1154(3-4), 237-282 (1993)

14. Gabius, S., Joshi, S., Kayser, K., Gabius, H.: The galactosidespecific lectin from mistletoe as biological response modifier. Int. J. Oncol. 1(6), 705-708 (1992)

15. Lee, R.T., Gabius, H.J., Lee, Y.C.: The sugar-combining area of the galactose-specific toxic lectin of mistletoe extends beyond the terminal sugar residue: comparison with a homologous toxic lectin, ricin. Carbohydr. Res. 254, 269-276 (1994)

16. Gupta, D., Kaltner, H., Dong, X., Gabius, H.J., Brewer, C.F.: Comparative cross-linking activities of lactose-specific plant and animal lectins and a natural lactose-binding immunoglobulin $\mathrm{G}$ fraction from human serum with asialofetuin. Glycobiology 6(8), 843-849 (1996)

17. Muthing, J., Burg, M., Mockel, B., Langer, M., Metelmann-Strupat, W., Werner, A., Neumann, U., Peter-Katalinic, J., Eck, J.: Preferential binding of the anticancer drug rViscumin (recombinant mistletoe lectin) to terminally alpha2-6-sialylated neolacto-series gangliosides. Glycobiology 12(8), 485-497 (2002)

18. Muthing, J., Meisen, I., Bulau, P., Langer, M., Witthohn, K., Lentzen, H., Neumann, U., Peter-Katalinic, J.: Mistletoe lectin I is a sialic acid-specific lectin with strict preference to gangliosides and glycoproteins with terminal Neu5Ac alpha 2-6Gal beta 1-4GlcNAc residues. Biochemistry 43(11), 2996-3007 (2004). doi:10.1021/bi0301892

19. Zwierzina, H., Bergmann, L., Fiebig, H., Aamdal, S., Schoffski, P., Witthohn, K., Lentzen, H.: The preclinical and clinical activity of aviscumine: a potential anticancer drug. Eur. J. Cancer 47(10), 1450-1457 (2011). doi:10.1016/j.ejca.2011.02.022

20. Yoon, T.J., Yoo, Y.C., Kang, T.B., Shimazaki, K., Song, S.K., Lee, K.H., Kim, S.H., Park, C.H., Azuma, I., Kim, J.B.: Lectins isolated from Korean mistletoe (Viscum album coloratum) induce apoptosis in tumor cells. Cancer Lett. 136(1), 33-40 (1999)

21. Lu, T.L., Chuang, J.Y., Yang, J.S., Chiu, S.T., Hsiao, N.W., Wu, M.C., Wu, S.H., Hsu, C.H.: Production of active nonglycosylated recombinant B-chain of type-2 ribosome-inactivating protein from viscum articulatum and its biological effects on peripheral blood mononuclear cells. Evid. Based Complement. Alternat. Med. 2011, 283747 (2011). doi:10.1155/2011/283747

22. Yoon, T.J., Yoo, Y.C., Kang, T.B., Song, S.K., Lee, K.B., Her, E., Song, K.S., Kim, J.B.: Antitumor activity of the Korean mistletoe lectin is attributed to activation of macrophages and NK cells. Arch. Pharm. Res. 26(10), 861-867 (2003)

23. Kang, T.B., Yoo, Y.C., Lee, K.H., Yoon, H.S., Her, E., Kim, J.B., Song, S.K.: Korean mistletoe lectin (KML-IIU) and its subchains induce nitric oxide $(\mathrm{NO})$ production in murine macrophage cells. J. Biomed. Sci. 15(2), 197-204 (2008). doi:10.1007/s11373-007-9210-2

24. Park, H.J., Hong, J.H., Kwon, H.J., Kim, Y., Lee, K.H., Kim, J.B., Song, S.K.: TLR4-mediated activation of mouse macrophages by Korean mistletoe lectin-C (KML-C). Biochem. Biophys. Res. Commun. 396(3), 721-725 (2010). doi:10.1016/j.bbrc.2010.04.169

25. Muraille, E., Pajak, B., Urbain, J., Leo, O.: Carbohydrate-bearing cell surface receptors involved in innate immunity: interleukin-12 induction by mitogenic and nonmitogenic lectins. Cell. Immunol. 191(1), 1-9 (1999). doi:10.1006/cimm.1998.1401
26. Panunto-Castelo, A., Souza, M.A., Roque-Barreira, M.C., Silva, J.S.: $\mathrm{KM}(+)$, a lectin from Artocarpus integrifolia, induces IL-12 p40 production by macrophages and switches from type 2 to type 1 cell-mediated immunity against Leishmania major antigens, resulting in $\mathrm{BALB} / \mathrm{c}$ mice resistance to infection. Glycobiology 11(12), 1035-1042 (2001)

27. Yoon, T.J., Yoo, Y.C., Kang, T.B., Her, E., Kim, S.H., Kim, K., Azuma, I., Kim, J.B.: Cellular and humoral adjuvant activity of lectins isolated from Korean mistletoe (Viscum album colaratum). Int. Immunopharmacol. 1(5), 881-889 (2001)

28. de Melo, C.M., de Castro, M.C., de Oliveira, A.P., Gomes, F.O., Pereira, V.R., Correia, M.T., Coelho, L.C., Paiva, P.M.: Immunomodulatory response of Cramoll 1,4 lectin on experimental lymphocytes. Phytother. Res. 24(11), 1631-1636 (2010). doi:10.1002/ptr.3156

29. Stojanovic, M.M., Zivkovic, I.P., Petrusic, V.Z., Kosec, D.J., Dimitrijevic, R.D., Jankov, R.M., Dimitrijevic, L.A., GavrovicJankulovic, M.D.: In vitro stimulation of Balb/c and C57 BL/6 splenocytes by a recombinantly produced banana lectin isoform results in both a proliferation of T cells and an increased secretion of interferon-gamma. Int. Immunopharmacol. 10(1), 120-129 (2009). doi:10.1016/j.intimp.2009.10.007

30. Dong, Q., Sugiura, T., Toyohira, Y., Yoshida, Y., Yanagihara, N., Karasaki, Y.: Stimulation of IFN-gamma production by garlic lectin in mouse spleen cells: involvement of IL-12 via activation of p38 MAPK and ERK in macrophages. Phytomedicine 18(4), 309-316 (2011). doi:10.1016/j.phymed.2010.06.008

31. Coltri, K.C., Oliveira, L.L., Ruas, L.P., Vendruscolo, P.E., Goldman, M.H., Panunto-Castelo, A., Roque-Barreira, M.C.: Protection against Paracoccidioides brasiliensis infection conferred by the prophylactic administration of native and recombinant ArtinM. Med. Mycol. 48(6), 792-799 (2010). doi:10.3109/ 13693780903501671

32. Unitt, J., Hornigold, D.: Plant lectins are novel Toll-like receptor agonists. Biochem. Pharmacol. 81(11), 1324-1328 (2011). doi:10.1016/j.bcp.2011.03.010

33. Rogerio, A.P., Cardoso, C.R., Fontanari, C., Souza, M.A., Afonso-Cardoso, S.R., Silva, E.V., Koyama, N.S., Basei, F.L., Soares, E.G., Calixto, J.B., Stowell, S.R., Dias-Baruffi, M., Faccioli, L.H.: Anti-asthmatic potential of a D-galactosebinding lectin from Synadenium carinatum latex. Glycobiology 17(8), 795-804 (2007). doi:10.1093/glycob/cwm053

34. Carter 3rd, J.E., Yu, J., Choi, N.W., Hough, J., Henderson, D., He, D., Langridge, W.H.: Bacterial and plant enterotoxin B subunit-autoantigen fusion proteins suppress diabetes insulitis. Mol. Biotechnol. 32(1), 1-15 (2006). doi:10.1385/MB:32:1:001

35. Carter 3rd, J.E., Odumosu, O., Langridge, W.H.: Expression of a ricin toxin $\mathrm{B}$ subunit: insulin fusion protein in edible plant tissues. Mol. Biotechnol. 44(2), 90-100 (2010). doi:10.1007/ s12033-009-9217-1

36. Azizi, A., Kumar, A., Diaz-Mitoma, F., Mestecky, J.: Enhancing oral vaccine potency by targeting intestinal M cells. PLoS Pathog. 6(11), e1001147 (2010). doi:10.1371/journal.ppat.1001147

37. Jang, M.H., Kweon, M.N., Iwatani, K., Yamamoto, M., Terahara, K., Sasakawa, C., Suzuki, T., Nochi, T., Yokota, Y., Rennert, P.D., Hiroi, T., Tamagawa, H., Iijima, H., Kunisawa, J., Yuki, Y., Kiyono, H.: Intestinal villous M cells: an antigen entry site in the mucosal epithelium. Proc. Natl. Acad. Sci. U. S. A. 101(16), 6110-6115 (2004). doi:10.1073/pnas.0400969101

38. Manocha, M., Pal, P.C., Chitralekha, K.T., Thomas, B.E., Tripathi, V., Gupta, S.D., Paranjape, R., Kulkarni, S., Rao, D.N.: Enhanced mucosal and systemic immune response with intranasal immunization of mice with HIV peptides entrapped in PLG microparticles in combination with Ulex Europaeus-I lectin as M cell target. Vaccine 23(48-49), 5599-5617 (2005). doi:10.1016/j.vaccine.2005.06.031

39. Wang, X., Kochetkova, I., Haddad, A., Hoyt, T., Hone, D.M., Pascual, D.W.: Transgene vaccination using Ulex europaeus 
agglutinin I (UEA-1) for targeted mucosal immunization against HIV-1 envelope. Vaccine 23(29), 3836-3842 (2005). doi:10.1016/ j.vaccine.2005.02.023

40. Chionh, Y.T., Wee, J.L., Every, A.L., Ng, G.Z., Sutton, P.: M-cell targeting of whole killed bacteria induces protective immunity against gastrointestinal pathogens. Infect. Immun. 77(7), 29622970 (2009). doi:10.1128/IAI.01522-08

41. Gupta, P.N., Vyas, S.P.: Investigation of lectinized liposomes as M-cell targeted carrier-adjuvant for mucosal immunization. Colloids Surf. B: Biointerfaces 82(1), 118-125 (2010). doi:10.1016/ j.colsurfb.2010.08.027

42. Hakomori, S.: Aberrant glycosylation in tumors and tumorassociated carbohydrate antigens. Adv. Cancer Res. 52, 257-331 (1989)

43. Dias-Baruffi, M., Cunha, F.Q., Ferreira, S.H., Roque-Barreira, M.C.: Macrophage-released neutrophil chemotactic factor (MNCF) induces PMN-neutrophil migration through lectin-like activity. Agents Actions 38 Spec No, C54-C56 (1993)

44. Bernardes, E.S., Silva, N.M., Ruas, L.P., Mineo, J.R., Loyola, A.M., Hsu, D.K., Liu, F.T., Chammas, R., Roque-Barreira, M.C.: Toxoplasma gondii infection reveals a novel regulatory role for galectin3 in the interface of innate and adaptive immunity. Am. J. Pathol. 168(6), 1910-1920 (2006). doi:10.2353/ajpath.2006.050636

45. Coltri, K.C., Casabona-Fortunato, A.S., Gennari-Cardoso, M.L., Pinzan, C.F., Ruas, L.P., Mariano, V.S., Martinez, R., Rosa, J.C., Panunto-Castelo, A., Roque-Barreira, M.C.: Paracoccin, a GlcNAcbinding lectin from Paracoccidioides brasiliensis, binds to laminin and induces TNF-alpha production by macrophages. Microbes Infect. 8(3), 704-713 (2006). doi:10.1016/j.micinf.2005.09.008

46. Lourenco, E.V., Pereira, S.R., Faca, V.M., Coelho-Castelo, A.A., Mineo, J.R., Roque-Barreira, M.C., Greene, L.J., PanuntoCastelo, A.: Toxoplasma gondii micronemal protein $\mathrm{MIC1}$ is a lactose-binding lectin. Glycobiology 11(7), 541-547 (2001)

47. Ganiko, L., Puccia, R., Mariano, V.S., Sant'Anna, O.A., Freymuller, E., Roque-Barreira, M.C., Travassos, L.R.: Paracoccin, an N-acetylglucosamine-binding lectin of Paracoccidioides brasiliensis, is involved in fungal growth. Microbes Infect 9(6), 695-703 (2007). doi:10.1016/j.micinf.2007.02.012

48. Dias-Baruffi, M., Sakamoto, M., Rossetto, S., Vozari-Hampe, M.M., Roque-Barreira, M.C.: Neutrophil migration and aggregation induced by euphorbin, a lectin from the latex of Euphorbia milii, var. milii. Inflamm. Res. 49(12), 732-736 (2000)

49. Santos-de-Oliveira, R., Dias-Baruffi, M., Thomaz, S.M., Beltramini, L.M., Roque-Barreira, M.C.: A neutrophil migrationinducing lectin from Artocarpus integrifolia. J. Immunol. 153(4), 1798-1807 (1994)

50. Roque-Barreira, M.C., Campos-Neto, A.: Jacalin: an IgA-binding lectin. J. Immunol. 134(3), 1740-1743 (1985)

51. Kondoh, H., Kobayashi, K., Hagiwara, K.: A simple procedure for the isolation of human secretory $\operatorname{IgA}$ of $\operatorname{IgA} 1$ and $\operatorname{IgA} 2$ subclass by a jackfruit lectin, jacalin, affinity chromatography. Mol. Immunol. 24(11), 1219-1222 (1987)

52. Bausch, J.N., Poretz, R.D.: Purification and properties of the hemagglutinin from Maclura pomifera seeds. Biochemistry 16 (26), 5790-5794 (1977)

53. Peumans, W.J., Winter, H.C., Bemer, V., Van Leuven, F., Goldstein, I.J., Truffa-Bachi, P., Van Damme, E.J.: Isolation of a novel plant lectin with an unusual specificity from Calystegia sepium. Glycoconj. J. 14(2), 259-265 (1997)

54. Van Damme, E.J., Barre, A., Verhaert, P., Rouge, P., Peumans, W.J.: Molecular cloning of the mitogenic mannose/maltose-specific rhizome lectin from Calystegia sepium. FEBS Lett. 397(2-3), 352-356 (1996)

55. Van Damme, E.J., Barre, A., Mazard, A.M., Verhaert, P., Horman, A., Debray, H., Rouge, P., Peumans, W.J.: Characterization and molecular cloning of the lectin from Helianthus tuberosus. Eur. J. Biochem. / FEBS 259(1-2), 135-142 (1999)
56. Zhang, W., Peumans, W.J., Barre, A., Astoul, C.H., Rovira, P., Rouge, P., Proost, P., Truffa-Bachi, P., Jalali, A.A., Van Damme, E.J.: Isolation and characterization of a jacalin-related mannosebinding lectin from salt-stressed rice (Oryza sativa) plants. Planta 210(6), 970-978 (2000)

57. Peumans, W.J., Zhang, W., Barre, A., Houles Astoul, C., BalintKurti, P.J., Rovira, P., Rouge, P., May, G.D., Van Leuven, F., Truffa-Bachi, P., Van Damme, E.J.: Fruit-specific lectins from banana and plantain. Planta 211(4), 546-554 (2000)

58. Nomura, K., Nakamura, S., Fujitake, M., Nakanishi, T.: Complete amino acid sequence of Japanese chestnut agglutinin. Biochem. Biophys. Res. Commun. 276(1), 23-28 (2000). doi:10.1006/ bbrc. 2000.3420

59. Mann, K., Farias, C.M., Del Sol, F.G., Santos, C.F., Grangeiro, T.B., Nagano, C.S., Cavada, B.S., Calvete, J.J.: The amino-acid sequence of the glucose/mannose-specific lectin isolated from Parkia platycephala seeds reveals three tandemly arranged jacalin-related domains. Eur. J. Biochem. / FEBS 268(16), 4414-4422 (2001)

60. Geshi, N., Brandt, A.: Two jasmonate-inducible myrosinasebinding proteins from Brassica napus $\mathrm{L}$. seedlings with homology to jacalin. Planta 204(3), 295-304 (1998)

61. Van Damme, E.J., Hause, B., Hu, J., Barre, A., Rouge, P., Proost, P., Peumans, W.J.: Two distinct jacalin-related lectins with a different specificity and subcellular location are major vegetative storage proteins in the bark of the black mulberry tree. Plant Physiol. 130(2), 757-769 (2002). doi:10.1104/pp.005892

62. Pereira-da-Silva, G., Roque-Barreira, M.C., Van Damme, E.J.: Artin $\mathrm{M}$ : a rational substitution for the names artocarpin and $\mathrm{KM}+$. Immunol. Lett. 119(1-2), 114-115 (2008). doi:10.1016/j.imlet.2008.06.002

63. Rosa, J.C., De Oliveira, P.S., Garratt, R., Beltramini, L., Resing, K., Roque-Barreira, M.C., Greene, L.J.: KM+, a mannosebinding lectin from Artocarpus integrifolia: amino acid sequence, predicted tertiary structure, carbohydrate recognition, and analysis of the beta-prism fold. Protein Sci. 8(1), 13-24 (1999). doi:10.1110/ps.8.1.13

64. Young, N.M., Johnston, R.A., Watson, D.C.: The amino acid sequences of jacalin and the Maclura pomifera agglutinin. FEBS Lett. 282(2), 382-384 (1991)

65. Ngoc, L.D., Brillard, M., Hoebeke, J.: The alpha- and betasubunits of the jacalins are cleavage products from a $17-\mathrm{kDa}$ precursor. Biochim. Biophys. Acta 1156(2), 219-222 (1993)

66. Jeyaprakash, A.A., Srivastav, A., Surolia, A., Vijayan, M.: Structural basis for the carbohydrate specificities of artocarpin: variation in the length of a loop as a strategy for generating ligand specificity. J. Mol. Biol. 338(4), 757-770 (2004). doi:10.1016/ j.jmb.2004.03.040

67. Pratap, J.V., Jeyaprakash, A.A., Rani, P.G., Sekar, K., Surolia, A., Vijayan, M.: Crystal structures of artocarpin, a Moraceae lectin with mannose specificity, and its complex with methyl-alpha-Dmannose: implications to the generation of carbohydrate specificity. J. Mol. Biol. 317(2), 237-247 (2002). doi:10.1006/ jmbi.2001.5432

68. Lerouge, P., Cabanes-Macheteau, M., Rayon, C., Fischette-Laine, A.C., Gomord, V., Faye, L.: N-glycoprotein biosynthesis in plants: recent developments and future trends. Plant Mol. Biol. 38(1-2), 31-48 (1998). doi:10.1023/A:1006012005654

69. Nakamura-Tsuruta, S., Uchiyama, N., Peumans, W.J., Van Damme, E.J., Totani, K., Ito, Y., Hirabayashi, J.: Analysis of the sugar-binding specificity of mannose-binding-type Jacalinrelated lectins by frontal affinity chromatography - an approach to functional classification. FEBS J. 275(6), 1227-1239 (2008). doi:10.1111/j.1742-4658.2008.06282.x

70. daSilva, L.L., de Molfetta-Machado, J.B., Panunto-Castelo, A., Denecke, J., Goldman, G.H., Roque-Barreira, M.C., Goldman, M.H.: cDNA cloning and functional expression of $\mathrm{KM}+$, the mannose-binding lectin from Artocarpus integrifolia seeds. 
Biochim. Biophys. Acta 1726(3), 251-260 (2005). doi:10.1016/ j.bbagen.2005.09.006

71. Pesquero, N.C., Pedroso, M.M., Watanabe, A.M., Goldman, M.H., Faria, R.C., Roque-Barreira, M.C., Bueno, P.R.: Realtime monitoring and kinetic parameter estimation of the affinity interaction of jArtinM and $\mathrm{rArtinM}$ with peroxidase glycoprotein by the electrogravimetric technique. Biosens. Bioelectron. 26(1), 36-42 (2010). doi:10.1016/j.bios.2010.04.047

72. Pranchevicius, M.C., Oliveira, L.L., Rosa, J.C., Avanci, N.C., Quiapim, A.C., Roque-Barreira, M.C., Goldman, M.H.: Characterization and optimization of ArtinM lectin expression in Escherichia coli. BMC Biotechnol. 12, 44 (2012). doi:10.1186/14726750-12-44

73. Trinchieri, G., Wysocka, M., D’Andrea, A., Rengaraju, M., AsteAmezaga, M., Kubin, M., Valiante, N.M., Chehimi, J.: Natural killer cell stimulatory factor (NKSF) or interleukin-12 is a key regulator of immune response and inflammation. Prog Growth Factor Res 4(4), 355-368 (1992)

74. Coltri, K.C., Oliveira, L.L., Pinzan, C.F., Vendruscolo, P.E., Martinez, R., Goldman, M.H., Panunto-Castelo, A., RoqueBarreira, M.C.: Therapeutic administration of KM+ lectin protects mice against Paracoccidioides brasiliensis infection via interleukin-12 production in a toll-like receptor 2-dependent mechanism. Am. J. Pathol. 173(2), 423-432 (2008). doi:10.2353/ajpath.2008.080126

75. Teixeira, C.R., Cavassani, K.A., Gomes, R.B., Teixeira, M.J., Roque-Barreira, M.C., Cavada, B.S., da Silva, J.S., Barral, A., Barral-Netto, M.: Potential of KM+lectin in immunization against Leishmania amazonensis infection. Vaccine 24(15), 3001-3008 (2006). doi:10.1016/j.vaccine.2005.11.067

76. Takeda, K., Akira, S.: Toll receptors and pathogen resistance. Cell. Microbiol. 5(3), 143-153 (2003)

77. West, A.P., Koblansky, A.A., Ghosh, S.: Recognition and signaling by toll-like receptors. Annu. Rev. Cell Dev. Biol. 22, 409-437 (2006). doi:10.1146/annurev.cellbio.21.122303.115827

78. Akira, S., Uematsu, S., Takeuchi, O.: Pathogen recognition and innate immunity. Cell 124(4), 783-801 (2006). doi:10.1016/ j.cell.2006.02.015

79. Choe, J., Kelker, M.S., Wilson, I.A.: Crystal structure of human toll-like receptor 3 (TLR3) ectodomain. Science 309(5734), 581585 (2005). doi:10.1126/science. 1115253

80. Weber, A.N., Morse, M.A., Gay, N.J.: Four N-linked glycosylation sites in human toll-like receptor 2 cooperate to direct efficient biosynthesis and secretion. J. Biol. Chem. 279(33), 34589-34594 (2004). doi:10.1074/jbc.M403830200

81. da Silva Correia, J., Ulevitch, R.J.: MD-2 and TLR4 N-linked glycosylations are important for a functional lipopolysaccharide receptor. J. Biol. Chem. 277(3), 1845-1854 (2002). doi:10.1074/ jbc.M109910200

82. Ohnishi, T., Muroi, M., Tanamoto, K.: MD-2 is necessary for the toll-like receptor 4 protein to undergo glycosylation essential for its translocation to the cell surface. Clin. Diagn. Lab. Immunol. 10(3), 405-410 (2003)

83. Ohnishi, T., Muroi, M., Tanamoto, K.: N-linked glycosylations at $\mathrm{Asn}(26)$ and $\mathrm{Asn}(114)$ of human MD-2 are required for toll-like receptor 4-mediated activation of NF-kappaB by lipopolysaccharide. J. Immunol. 167(6), 3354-3359 (2001)

84. Kataoka, H., Yasuda, M., Iyori, M., Kiura, K., Narita, M., Nakata, T., Shibata, K.: Roles of N-linked glycans in the recognition of microbial lipopeptides and lipoproteins by TLR2. Cell. Microbiol. 8 (7), 1199-1209 (2006). doi:10.1111/j.1462-5822.2006.00702.x

85. Kuka, M., Baronio, R., Valentini, S., Monaci, E., Muzzi, A., Aprea, S., De Gregorio, E., D’Oro, U.: Src kinases are required for a balanced production of IL-12/IL-23 in human dendritic cells activated by Toll-like receptor agonists. PLoS One 5(7), e11491 (2010). doi:10.1371/journal.pone.0011491
86. Li, F., Thiele, I., Jamshidi, N., Palsson, B.O.: Identification of potential pathway mediation targets in Toll-like receptor signaling. PLoS Comput. Biol. 5(2), e1000292 (2009). doi:10.1371/ journal.pcbi. 1000292

87. Brodskyn, C., de Oliveira, C.I., Barral, A., Barral-Netto, M.: Vaccines in leishmaniasis: advances in the last five years. Expert. Rev. Vaccines 2(5), 705-717 (2003). doi:10.1586/14760584.2.5.705

88. Martinez, J.E., Alba, Arias, L., Escobar, M.A., Saravia, N.G.: Haemoculture of Leishmania (Viannia) braziliensis from two cases of mucosal leishmaniasis: re-examination of haematogenous dissemination. Trans. R. Soc. Trop. Med. Hyg. 86(4), 392-394 (1992)

89. Marsden, P.D.: Mucosal leishmaniasis ("espundia" Escomel, 1911). Trans. R. Soc. Trop. Med. Hyg. 80(6), 859-876 (1986)

90. de Magalhaes, A.V., Moraes, M.A., Raick, A.N., Llanos-Cuentas, A., Costa, J.M., Cuba, C.C., Marsden, P.D.: Histopathology of tegumentary leishmaniasis caused by Leishmania braziliensis braziliensis. 3. Cellular reactions in tissues. Rev Inst Med Trop Sao Paulo 28(5), 300-311 (1986)

91. Childs, G.E., Lightner, L.K., McKinney, L., Groves, M.G., Price, E.E., Hendricks, L.D.: Inbred mice as model hosts for cutaneous leishmaniasis. I. Resistance and susceptibility to infection with Leishmania braziliensis, L. mexicana, and L. aethiopica. Ann. Trop. Med. Parasitol. 78(1), 25-34 (1984)

92. Sacks, D., Anderson, C.: Re-examination of the immunosuppressive mechanisms mediating non-cure of Leishmania infection in mice. Immunol. Rev. 201, 225-238 (2004). doi:10.1111/j.01052896.2004.00185.x

93. Gumy, A., Louis, J.A., Launois, P.: The murine model of infection with Leishmania major and its importance for the deciphering of mechanisms underlying differences in Th cell differentiation in mice from different genetic backgrounds. Int. J. Parasitol. 34(4), 433-444 (2004). doi:10.1016/j.ijpara.2003.11.021

94. Sacks, D., Noben-Trauth, N.: The immunology of susceptibility and resistance to Leishmania major in mice. Nat. Rev. Immunol. 2(11), 845-858 (2002). doi:10.1038/nri933

95. Reis, A.B., Giunchetti, R.C., Carrillo, E., Martins-Filho, O.A., Moreno, J.: Immunity to Leishmania and the rational search for vaccines against canine leishmaniasis. Trends Parasitol. 26(7), 341-349 (2010). doi:10.1016/j.pt.2010.04.005

96. Muller, I., Kropf, P., Etges, R.J., Louis, J.A.: Gamma interferon response in secondary Leishmania major infection: role of CD8+ T cells. Infect. Immun. 61(9), 3730-3738 (1993)

97. Borges-Walmsley, M.I., Chen, D., Shu, X., Walmsley, A.R.: The pathobiology of Paracoccidioides brasiliensis. Trends Microbiol. 10(2), 80-87 (2002)

98. Brummer, E., Castaneda, E., Restrepo, A.: Paracoccidioidomycosis: an update. Clin. Microbiol. Rev. 6(2), 89-117 (1993)

99. McEwen, J.G., Bedoya, V., Patino, M.M., Salazar, M.E., Restrepo, A.: Experimental murine paracoccidiodomycosis induced by the inhalation of conidia. J Med Vet Mycol 25(3), $165-175$ (1987)

100. Tobon, A.M., Agudelo, C.A., Osorio, M.L., Alvarez, D.L., Arango, M., Cano, L.E., Restrepo, A.: Residual pulmonary abnormalities in adult patients with chronic paracoccidioidomycosis: prolonged follow-up after itraconazole therapy. Clin. Infect. Dis. 37(7), 898904 (2003). doi: $10.1086 / 377538$

101. Singer-Vermes, L.M., Caldeira, C.B., Burger, E., Calich, L.G.: Experimental murine paracoccidioidomycosis: relationship among the dissemination of the infection, humoral and cellular immune responses. Clin. Exp. Immunol. 94(1), 75-79 (1993)

102. Mota, N.G., Rezkallah-Iwasso, M.T., Peracoli, M.T., Audi, R.C., Mendes, R.P., Marcondes, J., Marques, S.A., Dillon, N.L., Franco, M.F.: Correlation between cell-mediated immunity and clinical forms of paracoccidioidomycosis. Trans. R. Soc. Trop. Med. Hyg. 79(6), 765-772 (1985) 
103. Arango, M., Yarzabal, L.: T-cell dysfunction and hyperimmunoglobulinemia $\mathrm{E}$ in paracoccidioidomycosis. Mycopathologia 79 (2), 115-123 (1982)

104. Oliveira, S.J., Mamoni, R.L., Musatti, C.C., Papaiordanou, P.M., Blotta, M.H.: Cytokines and lymphocyte proliferation in juvenile and adult forms of paracoccidioidomycosis: comparison with infected and non-infected controls. Microbes Infect. 4(2), 139-144 (2002)

105. Benard, G., Romano, C.C., Cacere, C.R., Juvenale, M., MendesGiannini, M.J., Duarte, A.J.: Imbalance of IL-2, IFN-gamma and IL-10 secretion in the immunosuppression associated with human paracoccidioidomycosis. Cytokine 13(4), 248-252 (2001). doi:10.1006/cyto.2000.0824

106. Karhawi, A.S., Colombo, A.L., Salomao, R.: Production of IFNgamma is impaired in patients with paracoccidioidomycosis during active disease and is restored after clinical remission. Med. Mycol. 38(3), 225-229 (2000)

107. Kashino, S.S., Fazioli, R.A., Cafalli-Favati, C., Meloni-Bruneri, L.H., Vaz, C.A., Burger, E., Singer, L.M., Calich, V.L.: Resistance to Paracoccidioides brasiliensis infection is linked to a preferential Th1 immune response, whereas susceptibility is associated with absence of IFN-gamma production. J. Interferon Cytokine Res. 20(1), 89-97 (2000). doi:10.1089/107999000312766

108. Calich, V.L., Kashino, S.S.: Cytokines produced by susceptible and resistant mice in the course of Paracoccidioides brasiliensis infection. Braz. J. Med. Biol. Res 31(5), 615-623 (1998)

109. Cano, L.E., Kashino, S.S., Arruda, C., Andre, D., Xidieh, C.F., Singer-Vermes, L.M., Vaz, C.A., Burger, E., Calich, V.L.: Protective role of gamma interferon in experimental pulmonary paracoccidioidomycosis. Infect. Immun. 66(2), 800-806 (1998)

110. Souto, J.T., Figueiredo, F., Furlanetto, A., Pfeffer, K., Rossi, M.A., Silva, J.S.: Interferon-gamma and tumor necrosis factoralpha determine resistance to Paracoccidioides brasiliensis infection in mice. Am. J. Pathol. 156(5), 1811-1820 (2000)

111. Moreira, A.P., Dias-Melicio, L.A., Soares, A.M.: Interleukin-10 but not transforming growth factor beta inhibits murine activated macrophages Paracoccidioides brasiliensis killing: effect on H2O2 and NO production. Cell Immunol 263(2), 196-203. doi:10.1016/j.cellimm.2010.03.016

112. Moreira, A.P., Dias-Melicio, L.A., Peracoli, M.T., Calvi, S.A., Victoriano de Campos Soares, A.M.: Killing of Paracoccidioides brasiliensis yeast cells by IFN-gamma and TNF-alpha activated murine peritoneal macrophages: evidence of $\mathrm{H}(2) \mathrm{O}(2)$ and $\mathrm{NO}$ effector mechanisms. Mycopathologia 166(1), 17-23 (2008). doi:10.1007/s11046-007-9046-3

113. Gonzalez, A., de Gregori, W., Velez, D., Restrepo, A., Cano, L.E.: Nitric oxide participation in the fungicidal mechanism of gamma interferon-activated murine macrophages against Paracoccidioides brasiliensis conidia. Infect. Immun. 68(5), 2546-2552 (2000)

114. Ruas, L.P., Carvalho, F.C., Roque-Barreira, M.C.: ArtinM offers new perspectives in the development of antifungal therapy. Front. Microbiol. 3, 218 (2012). doi:10.3389/fmicb.2012.00218

115. Pot, C., Apetoh, L., Awasthi, A., Kuchroo, V.K.: Molecular pathways in the induction of interleukin-27-driven regulatory type 1 cells. J. Interf. Cytokine Res. Off. J. Int. Soc. Interf. Cytokine Res. 30(6), 381-388 (2010). doi:10.1089/jir.2010.0047

116. Xu, M., Mizoguchi, I., Morishima, N., Chiba, Y., Mizuguchi, J., Yoshimoto, T.: Regulation of antitumor immune responses by the IL-12 family cytokines, IL-12, IL-23, and IL-27. Clin. Dev. Immunol. 2010 (2010). doi:10.1155/2010/832454

117. Moreno, A.N., Jamur, M.C., Oliver, C., Roque-Barreira, M.C.: Mast cell degranulation induced by lectins: effect on neutrophil recruitment. Int. Arch. Allergy Immunol. 132(3), 221-230 (2003). doi:10.1159/000074303

118. Cardoso, M.R., Mota, C.M., Ribeiro, D.P., Santiago, F.M., Carvalho, J.V., Araujo, E.C., Silva, N.M., Mineo, T.W., Roque-Barreira, M.C., Mineo, J.R., Silva, D.A.: ArtinM, a d-mannose-binding lectin from
Artocarpus integrifolia, plays a potent adjuvant and immunostimulatory role in immunization against Neospora caninum. Vaccine (2011). doi:10.1016/j.vaccine.2011.09.136

119. Reis, E.A., Athanazio, D.A., Cavada, B.S., Teixeira, E.H., de Paulo Teixeira Pinto, V., Carmo, T.M., Reis, A., Trocolli, G., Croda, J., Harn, D., Barral-Netto, M., Reis, M.G.: Potential immunomodulatory effects of plant lectins in Schistosoma mansoni infection. Acta Trop. 108(2-3), 160-165 (2008). doi:10.1016/j.actatropica.2008.05.025

120. Figueiredo, J.G., Bitencourt, F.S., Mota, M.R., Silvestre, P.P., Aguiar, C.N., Benevides, R.G., Nascimento, K.S., de Moura, T.R., Dal-Secco, D., Assreuy, A.M., Cunha Fde, Q., Vale, M.R., Cavada, B.S., Alencar, N.M.: Pharmacological analysis of the neutrophil migration induced by D. rostrata lectin: involvement of cytokines and nitric oxide. Toxicon Off. J. Int. Soc. Toxinol. 54 (6), 736-744 (2009). doi:10.1016/j.toxicon.2009.05.037

121. Lyu, S.Y., Park, W.B.: Mistletoe lectin transport by M-cells in follicle-associated epithelium (FAE) and IL-12 secretion in dendritic cells situated below FAE in vitro. Arch. Pharm. Res. 33(9), 1433-1441 (2010). doi:10.1007/s12272-010-0918-6

122. Pelletier, M., Lavastre, V., Savoie, A., Ratthe, C., Saller, R., Hostanska, K., Girard, D.: Modulation of interleukin-15induced human neutrophil responses by the plant lectin Viscum album agglutinin-I. Clin. Immunol. 101(2), 229-236 (2001). doi:10.1006/clim.2001.5105

123. Hostanska, K., Hajto, T., Spagnoli, G.C., Fischer, J., Lentzen, H., Herrmann, R.: A plant lectin derived from Viscum album induces cytokine gene expression and protein production in cultures of human peripheral blood mononuclear cells. Nat. Immun. 14(5-6), 295-304 (1995)

124. Stanilova, S.A., Dobreva, Z.G., Slavov, E.S., Miteva, L.D.: C3 binding glycoprotein from Cuscuta europea induced different cytokine profiles from human PBMC compared to other plant and bacterial immunomodulators. Int. Immunopharmacol. 5(4), 723-734 (2005). doi:10.1016/j.intimp.2004.12.003

125. Toledo, K.A., Scwartz, C., Oliveira, A.F., Conrado, M.C., Bernardes, E.S., Fernandes, L.C., Roque-Barreira, M.C., Pereira-daSilva, G., Moreno, A.N.: Neutrophil activation induced by ArtinM: release of inflammatory mediators and enhancement of effector functions. Immunol. Lett. 123(1), 14-20 (2009). doi:10.1016/ j.imlet.2009.01.009

126. Pereira-da-Silva, G., Moreno, A.N., Marques, F., Oliver, C., Jamur, M.C., Panunto-Castelo, A., Roque-Barreira, M.C.: Neutrophil activation induced by the lectin $\mathrm{KM}+$ involves binding to CXCR2. Biochim. Biophys. Acta 1760(1), 86-94 (2006). doi:10.1016/j.bbagen.2005.09.011

127. Ganiko, L., Martins, A.R., Freymuller, E., Mortara, R.A., RoqueBarreira, M.C.: Lectin KM+-induced neutrophil haptotaxis involves binding to laminin. Biochim. Biophys. Acta 1721(1-3), 152-163 (2005). doi:10.1016/j.bbagen.2004.10.012

128. Ganiko, L., Martins, A.R., Espreafico, E.M., Roque-Barreira, M.C.: Neutrophil haptotaxis induced by the lectin KM+. Glycoconj. J. 15(5), 527-530 (1998)

129. de Almeida Buranello, P.A., Moulin, M.R., Souza, D.A., Jamur, M.C., Roque-Barreira, M.C., Oliver, C.: The lectin ArtinM induces recruitment of rat mast cells from the bone marrow to the peritoneal cavity. PLoS One 5(3), e9776 (2010). doi:10.1371/ journal.pone.0009776

130. Novak, N., Yu, C.F., Bieber, T., Allam, J.P.: Toll-like receptor 7 agonists and skin. Drug News Perspect. 21(3), 158-165 (2008)

131. Othoro, C., Johnston, D., Lee, R., Soverow, J., Bystryn, J.C., Nardin, E.: Enhanced immunogenicity of Plasmodium falciparum peptide vaccines using a topical adjuvant containing a potent synthetic Toll-like receptor 7 agonist, imiquimod. Infect. Immun. 77(2), 739-748 (2009). doi:10.1128/IAI.00974-08

132. Modabber, F., Buffet, P.A., Torreele, E., Milon, G., Croft, S.L.: Consultative meeting to develop a strategy for treatment of 
cutaneous leishmaniasis. Institute Pasteur, Paris. 13-15 June, 2006. Kinetoplastid Biol. Dis. 6, 3 (2007). doi:10.1186/14759292-6-3

133. Arevalo, I., Ward, B., Miller, R., Meng, T.C., Najar, E., Alvarez, E., Matlashewski, G., Llanos-Cuentas, A.: Successful treatment of drug-resistant cutaneous leishmaniasis in humans by use of imiquimod, an immunomodulator. Clin. Infect. Dis. 33(11), 1847-1851 (2001). doi:10.1086/324161

134. Agrawal, S., Kandimalla, E.R.: Synthetic agonists of Toll-like receptors 7, 8 and 9. Biochem. Soc. Trans. 35(Pt 6), 1461-1467 (2007). doi:10.1042/BST0351461

135. Raman, V.S., Bhatia, A., Picone, A., Whittle, J., Bailor, H.R., O'Donnell, J., Pattabhi, S., Guderian, J.A., Mohamath, R.,
Duthie, M.S., Reed, S.G.: Applying TLR synergy in immunotherapy: implications in cutaneous leishmaniasis. J. Immunol. 185(3), 1701-1710 (2010). doi:10.4049/jimmunol.1000238

136. Loures, F.V., Pina, A., Felonato, M., Calich, V.L.: TLR2 is a negative regulator of Th17 cells and tissue pathology in a pulmonary model of fungal infection. J. Immunol. 183(2), 12791290 (2009). doi:10.4049/jimmunol.0801599

137. Custodio, L.A., Loyola, W., Conchon-Costa, I., da Silva Quirino, G.F., Felipe, I.: Protective effect of Artin M from extract of Artocarpus integrifolia seeds by Th1 and Th17 immune response on the course of infection by Candida albicans. Int. Immunopharmacol. 11(10), 1510-1515 (2011). doi:10.1016/j.intimp.2011.05.005 